\title{
Theoretical Investigation of Excited-State Intramolecular Double-Proton Transfer Mechanism of Substituent Modified 1, 3-Bis (2-pyridylimino)-4,7- dihydroxyisoindole in Dichloromethane Solution
}

Xiumin Liu

Dalian Polytechnic University

Wenzhi Li

Dalian Polytechnic University

Yuxi Wang

Dalian Polytechnic University

Yaping Tao

Dalian Polytechnic University

\section{Yi Wang}

Dalian Polytechnic University

Yingmin Hou ( $\nabla$ yingminhou@163.com )

Dalian Polytechnic University https://orcid.org/0000-0001-5178-4376

\section{Research Article}

Keywords: Excited-state intramolecular double-proton transfer, substituent modification, hydrogen bond, stepwise proton transfer, electron-withdrawing groups

Posted Date: May 27th, 2021

DOI: https://doi.org/10.21203/rs.3.rs-525517/v1

License: (a) (i) This work is licensed under a Creative Commons Attribution 4.0 International License. Read Full License 


\section{Abstract}

Density functional theory (DFT) and time-dependent DFT (TDDFT) methods were used to investigate substituent effects and excited-state intramolecular double-proton transfer in 1, 3-bis (2-pyridylimino)-4, 7dihydroxyisoindole (BPI-OH) and its derivatives. The results of a systematic study of the substituent effects of electron-withdrawing groups $(\mathrm{F}, \mathrm{Cl}$, and $\mathrm{Br})$ on the adjacent sites of the benzene ring were used to regulate the photophysical properties of the molecules and the dynamics of the proton-transfer process. Geometric structure comparisons and infrared spectroscopic analysis confirmed that strengthening of the intramolecular hydrogen bond in the first excited state $\left(\mathrm{S}_{1}\right)$ facilitated proton transfer. Functional analysis of the reduction density gradient confirmed these conclusions. Doubleproton transfer in $\mathrm{BPI}-\mathrm{OH}$ is considered to occur in two steps, i.e., $\mathrm{BPI}-\mathrm{OH}(\mathrm{N}) \rightarrow \mathrm{BPI}-\mathrm{OH}\left(\mathrm{T}_{1}\right) \rightarrow \mathrm{BPI}-\mathrm{OH}\left(\mathrm{T}_{2}\right)$, in the ground state $\left(\mathrm{S}_{0}\right)$ and the $\mathrm{S}_{1}$ state. The potential-energy curves for two-step proton transfer were scanned for both the $\mathrm{S}_{0}$ and $\mathrm{S}_{1}$ states to clarify the mechanisms and pathways of proton transfer. The stepwise path in which two protons are consecutively transferred has a low energy barrier and is more rational and favorable. This study shows that the presence or absence of coordinating groups, and the type of coordinating group, affect the hydrogen-bond strength. A coordinating group enhances hydrogenbond formation, i.e., it promotes excited-state intramolecular proton transfer.

\section{Introduction}

Proton transfer is an essential process in biology and chemistry. It can achieve interactions via formation of specific hydrogen bonds [1, 2]. Photochemical excited-state intramolecular proton transfer (ESIPT) of an enol to the proton-transferred keto isomer is usually accompanied by significant changes in the photophysical properties; this leads to a large Stokes shift [3-7]. Because of its distinct photophysical and photochemical effects, ESIPT has attracted much attention for use in various areas, e.g., white-lightemitting materials [8-10], fluorescence sensors [11], and biological probes [12-17]. Most reported physical processes involve single-proton transfer. However, in biological systems, multi-proton-transfer reactions also occur. For 2,5-bis(benzoxazol-2-yl)thiophene-3,4-diol, which has two proton-transfer sites, competitive mechanisms that involve $\mathrm{S}_{1}$ state single and double-proton transfers have been proposed [18]. A series of theoretical calculations have indicated stepwise or coordination mechanisms for excitedstate intramolecular double-proton transfer (ESIDPT) processes [19-21].

Hydrogen-bonding interactions are typically present in the microscopic frameworks of molecules and supramolecules, e.g., in proteins, DNA, and some polymers [22, 23]. Intramolecular hydrogen bonds are also formed between proton donors and acceptors, and are prerequisites for ESIPT reactions. The theory of excited-state hydrogen-bond strengthening, which was proposed by Han et al., has attracted significant attention in recent years [24-29]. In addition to hydrogen bonding, the substituents on donor and acceptor units, solvent polarity, and pH values of the surrounding media can affect the ESIPT rate [3033]. Some progress has been made in improving the photophysical properties of probes and sensors by using halogen atoms as coordinating groups. Piechowska's group reported that large Stokes shifts could 
be obtained by introducing electron-donating and electron-accepting groups into pyridine rings, and investigated the effects of such groups on the ESPT behavior of 10-hydroxy-11H-benzo[b]fluoren-11-one (HBQ) [34]. Yu et al. reported that the photophysical properties could be adjusted by introducing electronaccepting or electron-donating substituents into a phenolic ring [35].

Recently, the photo-physical behavior of 5,6-dichloro-1,3-bis(2-pyridylimino)-4,7-dihydroxyisoindole and the absorption and emission properties of ten isomers have been reported [36]. However, in this previous study, the effects of substituents on the ESIDPT process were not considered. Here, we systematically investigated the effects of different electron-withdrawing substituents $(\mathrm{F}, \mathrm{Cl}$, and $\mathrm{Br})$ in $\mathrm{BPI}-\mathrm{OH}$ on proton transfer in the $S_{0}$ and $S_{1}$ states. We used DFT and TDDFT methods to explore the effects of electronwithdrawing groups $(\mathrm{F}, \mathrm{Cl}$, and $\mathrm{Br})$; the geometric parameters, infrared (IR) spectra, and reduction density gradient (RDG) function were examined. The frontier molecular orbitals (FMOs) [37] and Mulliken's charge were used to predict the charge distribution. Most importantly, details of the ESIDPT mechanism were clarified by constructing the potential-energy curves (PECs) for the $S_{0}$ and $S_{1}$ states.

\section{Computational Details}

DFT/TDDFT calculations were performed using the Gaussian 16 program suite [38]. The geometric structures and reaction pathways were calculated without constraint by using the B3LYP function (Hybrid Becke, three-parameter, with 20\% Hartree-Fock exchange energy) with the TZVP basis set [39, 40]. Dichloromethane (DCM) was selected as the solvent in all caiculations on the basis of the integral equation formalism variant in the polarizable continuum model (IEFPCM) [41-43]. Vibration frequency calculations were performed to confirm each optimized structure corresponding to a local minimum (no imaginary frequency). The RDG function was introduced to investigate non-covalent interactions by using the Multiwfn program [44-46]. The PECs for the $S_{0}$ and $S_{1}$ states in double-proton transfer were obtained at the B3LYP/TZVP level.

\section{Results And Discussion}

\subsection{Geometric structures and IR vibrational spectra}

Calculations were performed at the B3LYP/TZVP level to determine the geometric configurations of BPI$\mathrm{OH}(\mathrm{N}), \mathrm{BPI}-\mathrm{OH}\left(\mathrm{T}_{1}\right)$, and $\mathrm{BPI}-\mathrm{OH}\left(\mathrm{T}_{2}\right)$ in $\mathrm{DCM}$; the results are shown in Fig. 1. The optimized geometric structures of $\mathrm{BPI}-\mathrm{OH}-\mathrm{F}, \mathrm{BPI}-\mathrm{OH}-\mathrm{Cl}$, and $\mathrm{BPI}-\mathrm{OH}-\mathrm{Br}$ are show in Fig. 2. The optimized geometries of $\mathrm{BPI}-\mathrm{OH}$ and its derivatives all have the same symmetry. The bond length of $\mathrm{O}_{1}-\mathrm{H}_{2}$ is the same as the bond length of $\mathrm{O}_{4}-\mathrm{H}_{5}$, and the $\mathrm{O}_{1}-\mathrm{H}_{2} \cdots \mathrm{N}_{3}$ bond angle is the same as the $\mathrm{O}_{4}-\mathrm{H}_{5} \cdots \mathrm{N}_{6}$ bond angle. Table 1 lists the hydrogen-bond lengths in $\mathrm{BPI}-\mathrm{OH}$ and its derivatives (normal structure) in the $\mathrm{S}_{0}$ and $\mathrm{S}_{1}$ states. The $\mathrm{O}_{1}-\mathrm{H}_{2}$ hydrogen bond length in BPI-OH $(\mathrm{N})$ is $0.9813 \AA$ in $\mathrm{S}_{0}$ state, and $0.9975 \AA$ in $\mathrm{S}_{1}$ state. For BPI-OH-F $(\mathrm{N})$, $\mathrm{BPI}-\mathrm{OH}-\mathrm{Cl}(\mathrm{N})$, and $\mathrm{BPI}-\mathrm{OH}-\mathrm{Br}(\mathrm{N})$, the $\mathrm{O}_{1}-\mathrm{H}_{2}$ bond lengths are $0.9832,0.9843$, and $0.9847 \AA$, respectively, in the $S_{0}$ state. These increase by $0.0189,0.0189$, and $0.0190 \AA$, respectively, to $1.0021,1.0032$, and 1.0037 
$\AA$, respectively, in the $\mathrm{S}_{1}$ state. In $\mathrm{BPI}-\mathrm{OH}-\mathrm{F}(\mathrm{N}), \mathrm{BPI}-\mathrm{OH}-\mathrm{Cl}(\mathrm{N})$, and $\mathrm{BPI}-\mathrm{OH}-\mathrm{Br}(\mathrm{N})$, the distances between hydroxyl groups are greater than the corresponding distances in $\mathrm{BPI}-\mathrm{OH}(\mathrm{N})$ in both the $\mathrm{S}_{0}$ and $\mathrm{S}_{1}$ states. This shows that the further apart the hydroxyl group is, the easier proton loss is; this is conducive to proton transfer. The $\mathrm{H}_{2}-\mathrm{N}_{3}$ hydrogen-bond length in $\mathrm{BPI}-\mathrm{OH}(\mathrm{N})$ is $2.0590 \AA$ in $\mathrm{S}_{0}$ state and $1.9486 \AA$ in $\mathrm{S}_{1}$ state. For BPI-OH-F (N), BPI-OH-Cl $(\mathrm{N})$, and $\mathrm{BPI}-\mathrm{OH}-\mathrm{Br}(\mathrm{N})$, the $\mathrm{H}_{2}-\mathrm{N}_{3}$ bond lengths are 2.0538, 2.0217, and $2.0104 \AA$, respectively, in the $S_{0}$ state. These decrease by $0.1263,0.1172$, and $0.1147 \AA$, respectively, to $1.9275,1.9045$, and $1.8957 \AA$, respectively, in the $\mathrm{S}_{1}$ state. For the BPI-OH $(\mathrm{N}), \mathrm{BPI}-\mathrm{OH}-\mathrm{F}(\mathrm{N}), \mathrm{BPI}-\mathrm{OH}-\mathrm{Cl}(\mathrm{N})$, and $\mathrm{BPI}-\mathrm{OH}-\mathrm{Br}(\mathrm{N})$, the $\mathrm{O}_{1}-\mathrm{H}_{2} \cdots \mathrm{N}_{3}$ bond angles change from $143.77^{\circ}, 143.42^{\circ}, 144.59^{\circ}$, and $144.99^{\circ}$ in the $S_{0}$ state to $147.27^{\circ}, 147.32^{\circ}, 148.21^{\circ}$, and $148.52^{\circ}$, respectively, in the $S_{1}$ state, i.e., they increase by $3.50^{\circ}$, $3.90^{\circ}, 3.62^{\circ}$, and $3.53^{\circ}$, respectively. In BPI-OH-Br $(\mathrm{N}), \mathrm{BPI}-\mathrm{OH}-\mathrm{Cl}(\mathrm{N})$, and $\mathrm{BPI}-\mathrm{OH}-\mathrm{F}(\mathrm{N})$, the bond angles tend to be larger than those in BPI-OH $(\mathrm{N})$. This shows that the presence of a ligand increases the ability of the proton acceptor to capture a proton.

Table 1

Calculated primary bond lengths $(\AA)$ and angles $\left(^{\circ}\right)$ for $\mathrm{BPI}-\mathrm{OH}(\mathrm{N}), \mathrm{BPI}-\mathrm{OH}-\mathrm{F}(\mathrm{N}), \mathrm{BPI}-\mathrm{OH}-\mathrm{Cl}(\mathrm{N})$, and $\mathrm{BPI}-\mathrm{OH}-\mathrm{Br}(\mathrm{N})$ in $\mathrm{S}_{0}$ and $\mathrm{S}_{1}$ states.

\begin{tabular}{|lllllllll|}
\hline & \multicolumn{2}{l}{ BPI-OH(N) } & \multicolumn{2}{l}{ BPI-OH-F(N) } & \multicolumn{2}{l|}{ BPI-OH-CI(N) } & \multicolumn{2}{l|}{ BPI-OH-Br(N) } \\
\hline parameter & $\mathrm{S}_{0}$ & $\mathrm{~S}_{1}$ & $\mathrm{~S}_{0}$ & $\mathrm{~S}_{1}$ & $\mathrm{~S}_{0}$ & $\mathrm{~S}_{1}$ & $\mathrm{~S}_{0}$ & $\mathrm{~S}_{1}$ \\
\hline $\mathrm{O}_{1}-\mathrm{H}_{2}$ & 0.9813 & 0.9975 & 0.9832 & 1.0021 & 0.9843 & 1.0032 & 0.9847 & 1.0037 \\
\hline $\mathrm{H}_{2}-\mathrm{N}_{3}$ & 2.0590 & 1.9486 & 2.0538 & 1.9275 & 2.0217 & 1.9045 & 2.0104 & 1.8957 \\
\hline$\delta\left(\mathrm{O}_{1}-\mathrm{H}_{2}-\mathrm{N}_{3}\right)$ & 143.77 & 147.27 & 143.42 & 147.32 & 144.59 & 148.21 & 144.99 & 148.52 \\
\hline $\mathrm{O}_{4}-\mathrm{H}_{5}$ & 0.9813 & 0.9975 & 0.9832 & 1.0021 & 0.9843 & 1.0032 & 0.9848 & 1.0038 \\
\hline $\mathrm{H}_{5}-\mathrm{N}_{6}$ & 2.0590 & 1.9486 & 2.0539 & 1.9275 & 2.0218 & 1.9044 & 2.0103 & 1.8968 \\
\hline$\delta\left(\mathrm{O}_{4}-\mathrm{H}_{5}-\mathrm{N}_{6}\right)$ & 143.80 & 147.37 & 143.42 & 147.32 & 144.59 & 148.21 & 144.99 & 148.47 \\
\hline
\end{tabular}

Table 2 shows the parameters for the BPI-OH $\left(\mathrm{T}_{1}\right), \mathrm{BPI}-\mathrm{OH}-\mathrm{F}\left(\mathrm{T}_{1}\right), \mathrm{BPI}-\mathrm{OH}-\mathrm{Cl}\left(\mathrm{T}_{1}\right)$, and BPI-OH-Br $\left(\mathrm{T}_{1}\right)$ structures, which were formed via ESIPT. In hydrogen-bonded $\mathrm{O}_{1}-\mathrm{H}_{2} \cdots \mathrm{N}_{3}$, the $\mathrm{O}_{1}-\mathrm{H}_{2}$ bond lengths are 2.1388, 2.1723, 2.1320, and 2.1244 $\AA$, respectively, in $S_{0}$ state, and 2.1637, 2.2158, 2.1838, and 2.1753 respectively, in the $S_{1}$ state. The $H_{2} \cdots N_{3}$ bond lengths are $1.0218,1.0207,1.0217$, and $1.0220 \AA$, respectively, in $\mathrm{S}_{0}$ state, and $1.0206,1.0188,1.0194,1.0196 \AA$, respectively, in the $\mathrm{S}_{1}$ state. The $\mathrm{O}_{1} \cdot \mathrm{H}_{2}-\mathrm{N}_{3}$ bond angle changes from $133.46^{\circ}, 132.73^{\circ}, 133.09^{\circ}$, and $133.14^{\circ}$ in $S_{0}$ state to $132.48^{\circ}, 131.43^{\circ}$, $131.46^{\circ}$, and $131.48^{\circ}$, respectively, in the $S_{1}$ state. This indicates that the hydrogen bond in $\mathrm{O}_{1} \cdots \mathrm{H}_{2}-\mathrm{N}_{3}$ is stronger in the $\mathrm{S}_{0}$ state. In hydrogen-bonded $\mathrm{O}_{4}-\mathrm{H}_{5} \cdots \mathrm{N}_{6}$, the $\mathrm{O}_{4}-\mathrm{H}_{5}$ bond lengths increase from 0.9806 , 
$0.9819,0.9829$, and $0.9835 \AA$ in $S_{0}$ state to $0.9861,0.9890,0.9902$, and $0.9908 \AA$, respectively, in the $\mathrm{S}_{1}$ state. The $\mathrm{H}_{5} \cdots \mathrm{N}_{6}$ bond lengths decrease from 2.0947, 2.0875, 2.0528, and $2.0372 \AA$, respectively, in the $\mathrm{S}_{0}$ state to $2.0362,2.0099,1.9817$, and $1.9696 \AA$, respectively, in the $\mathrm{S}_{1}$ state. The $\mathrm{O}_{4}-\mathrm{H}_{5}-\mathrm{N}_{6}$ hydrogen-bond angles in BPI-OH $\left(\mathrm{T}_{1}\right), \mathrm{BPI}-\mathrm{OH}-\mathrm{Br}\left(\mathrm{T}_{1}\right), \mathrm{BPI}-\mathrm{OH}-\mathrm{Cl}\left(\mathrm{T}_{1}\right)$, and BPI-OH-F $\left(\mathrm{T}_{1}\right)$ are $2.61^{\circ}, 2.67^{\circ}, 2.73^{\circ}$, and $2.88^{\circ}$, respectively, higher in the $S_{1}$ state than in the $S_{0}$ state. This data show that the bond angle increases with increasing electron absorption intensity after addition of a coordinating group. These observations indicate that the intramolecular hydrogen bonds become stronger with increasing electron absorption intensity, and are stronger in the $\mathrm{S}_{1}$ state than in the $\mathrm{S}_{0}$ state.

$\mathrm{BPI}-\mathrm{OH}\left(\mathrm{T}_{2}\right), \mathrm{BPI}-\mathrm{OH}-\mathrm{F}\left(\mathrm{T}_{2}\right), \mathrm{BPI}-\mathrm{OH}-\mathrm{Cl}\left(\mathrm{T}_{2}\right)$, and $\mathrm{BPI}-\mathrm{OH}-\mathrm{Br}\left(\mathrm{T}_{2}\right)$ are formed via two ESIPT processes, along with two corresponding hydrogen bonds. The $\mathrm{O}_{1} \cdots \mathrm{H}_{2}-\mathrm{N}_{3}$ is discussed because of its symmetrical structure. The data in Table 3 show that in the $\mathrm{S}_{0}$ state, the $\mathrm{O}_{1} \cdots \mathrm{H}_{2}$ and $\mathrm{H}_{2}-\mathrm{N}_{3}$ bond lengths in BPI-OH $\left(\mathrm{T}_{2}\right)$, BPI-OH-F $\left(\mathrm{T}_{2}\right), \mathrm{BPI}-\mathrm{OH}-\mathrm{Cl}\left(\mathrm{T}_{2}\right)$, and BPI-OH-Br $\left(\mathrm{T}_{2}\right)$ are 2.2752, 2.2878, 2.2512, and 2.2406 $\AA$, respectively, and $1.0155,1.0152,1.0157$, and $1.0159 \AA$, respectively. These are $2.2184,2.2380,2.2104$, and $2.2009 \AA$, respectively, and $1.0186,1.0181,1.0183 \AA$, and $1.0185 \AA$, respectively, higher in the $\mathrm{S}_{1}$ state. The $\mathrm{O}_{1} \cdots \mathrm{H}_{2}-\mathrm{N}_{3}$ bond angles change from $128.70^{\circ}, 128.88^{\circ}$, and $128.97^{\circ}$, respectively, in the $S_{0}$ state to $130.13^{\circ}, 129.96^{\circ}$, and $130.00^{\circ}$, respectively, in the $S_{1}$ state. These changes in the bond parameters prove that two intramolecular hydrogen bonds are strengthened on photoexcitation. The effect of hydrogen-bond enhancement is clearest when the coordinating group contains F. ESIPT is therefore promoted by the presence of a coordinating base and excited states.

Table 2

Calculated primary bond lengths $(\AA)$ and angles $\left({ }^{\circ}\right)$ for $\mathrm{BPI}-\mathrm{OH}\left(\mathrm{T}_{1}\right), \mathrm{BPI}-\mathrm{OH}-\mathrm{F}\left(\mathrm{T}_{1}\right), \mathrm{BPI}-\mathrm{OH}-\mathrm{Cl}\left(\mathrm{T}_{1}\right)$, and $\mathrm{BPI}-\mathrm{OH}-\mathrm{Br}\left(\mathrm{T}_{1}\right)$ in $\mathrm{S}_{0}$ and $\mathrm{S}_{1}$ states.

\begin{tabular}{|c|c|c|c|c|c|c|c|c|}
\hline \multirow[b]{2}{*}{ parameter } & \multicolumn{2}{|c|}{$\mathrm{BPI}-\mathrm{OH}\left(\mathrm{T}_{1}\right)$} & \multicolumn{2}{|c|}{$\mathrm{BPI-OH-F}\left(\mathrm{T}_{1}\right)$} & \multicolumn{2}{|c|}{$\mathrm{BPI}-\mathrm{OH}-\mathrm{Cl}\left(\mathrm{T}_{1}\right)$} & \multicolumn{2}{|c|}{ BPI-OH-Br(T $\left.1{ }^{2}\right)$} \\
\hline & $\mathrm{S}_{0}$ & $\mathrm{~S}_{1}$ & $\mathrm{~S}_{0}$ & $\mathrm{~S}_{1}$ & $\mathrm{~S}_{0}$ & $\mathrm{~S}_{1}$ & $\mathrm{~S}_{0}$ & $\mathrm{~S}_{1}$ \\
\hline $\mathrm{O}_{1}-\mathrm{H}_{2}$ & 2.1388 & 2.1637 & 2.1723 & 2.2158 & 2.1320 & 2.1838 & 2.1244 & 2.1753 \\
\hline $\mathrm{H}_{2}-\mathrm{N}_{3}$ & 1.0218 & 1.0206 & 1.0207 & 1.0188 & 1.0217 & 1.0194 & 1.0220 & 1.0196 \\
\hline$\delta\left(\mathrm{O}_{1}-\mathrm{H}_{2}-\mathrm{N}_{3}\right)$ & 133.46 & 132.48 & 132.73 & 131.43 & 133.09 & 131.46 & 133.14 & 131.48 \\
\hline $\mathrm{O}_{4}-\mathrm{H}_{5}$ & 0.9806 & 0.9861 & 0.9819 & 0.9890 & 0.9829 & 0.9902 & 0.9835 & 0.9908 \\
\hline $\mathrm{H}_{5}-\mathrm{N}_{6}$ & 2.0947 & 2.0362 & 2.0875 & 2.0099 & 2.0528 & 1.9817 & 2.0372 & 1.9696 \\
\hline$\delta\left(\mathrm{O}_{4}-\mathrm{H}_{5}-\mathrm{N}_{6}\right)$ & 142.84 & 145.45 & 142.52 & 145.40 & 143.81 & 146.54 & 144.26 & 146.93 \\
\hline
\end{tabular}


Table 3

Calculated primary bond lengths $(\AA)$ and angles $\left(^{\circ}\right)$ for BPI-OH $\left(\mathrm{T}_{2}\right)$, BPI-OH-F $\left(\mathrm{T}_{2}\right), \mathrm{BPI}-\mathrm{OH}-\mathrm{Cl}\left(\mathrm{T}_{2}\right)$, and $\mathrm{BPI}-\mathrm{OH}-\mathrm{Br}\left(\mathrm{T}_{2}\right)$ in $\mathrm{S}_{0}$ and $\mathrm{S}_{1}$ states.

\begin{tabular}{|c|c|c|c|c|c|c|c|c|}
\hline \multirow[b]{2}{*}{ parameter } & \multicolumn{2}{|c|}{$\mathrm{BPI}-\mathrm{OH}\left(\mathrm{T}_{2}\right)$} & \multicolumn{2}{|c|}{ BPI-OH-F(T $\left.\mathrm{T}_{2}\right)$} & \multicolumn{2}{|c|}{$\mathrm{BPI}-\mathrm{OH}-\mathrm{Cl}\left(\mathrm{T}_{2}\right)$} & \multicolumn{2}{|c|}{$\mathrm{BPI}-\mathrm{OH}-\mathrm{Br}\left(\mathrm{T}_{2}\right)$} \\
\hline & $\mathrm{S}_{0}$ & $S_{1}$ & $\mathrm{~S}_{0}$ & $S_{1}$ & $\mathrm{~S}_{0}$ & $\mathrm{~S}_{1}$ & $\mathrm{~S}_{0}$ & $\mathrm{~S}_{1}$ \\
\hline $\mathrm{O}_{1}-\mathrm{H}_{2}$ & 2.2752 & 2.2184 & 2.2878 & 2.2380 & 2.2512 & 2.2104 & 2.2406 & 2.2009 \\
\hline $\mathrm{H}_{2}-\mathrm{N}_{3}$ & 1.0155 & 1.0186 & 1.0152 & 1.0181 & 1.0157 & 1.0183 & 1.0159 & 1.0185 \\
\hline$\delta\left(\mathrm{O}_{1}-\mathrm{H}_{2}-\mathrm{N}_{3}\right)$ & 128.99 & 130.46 & 128.70 & 130.13 & 128.88 & 129.96 & 128.97 & 130.00 \\
\hline $\mathrm{O}_{4}-\mathrm{H}_{5}$ & 2.2750 & 2.2181 & 2.2882 & 2.2383 & 2.2512 & 2.2102 & 2.2407 & 2.2008 \\
\hline $\mathrm{H}_{5}-\mathrm{N}_{6}$ & 1.0155 & 1.0186 & 1.0152 & 1.0180 & 1.0157 & 1.0183 & 1.0159 & 1.0185 \\
\hline$\delta\left(\mathrm{O}_{4}-\mathrm{H}_{5}-\mathrm{N}_{6}\right)$ & 128.99 & 130.47 & 128.70 & 130.12 & 128.89 & 129.96 & 128.96 & 130.00 \\
\hline
\end{tabular}

The IR vibrational spectra of $\mathrm{BPI}-\mathrm{OH}$ and its derivatives were calculated. The stretching vibration frequencies on the $\mathrm{S}_{0}$ and $\mathrm{S}_{1}$ states for $\mathrm{BPI}-\mathrm{OH}, \mathrm{BPI}-\mathrm{OH}-\mathrm{F}, \mathrm{BPI}-\mathrm{OH}-\mathrm{Cl}$, and $\mathrm{BPI}-\mathrm{OH}-\mathrm{Br}$ are shown in Figs. 3 and 4. For BPI-OH (N), the $\mathrm{O}_{1}-\mathrm{H}_{2}$ stretching frequency is $3484 \mathrm{~cm}^{-1}$ in the $\mathrm{S}_{0}$ state and $3198 \mathrm{~cm}^{-1}$ in the $\mathrm{S}_{1}$ state. A red shift of $286 \mathrm{~cm}^{-1}$ was observed for the $\mathrm{S}_{1}$ state; this shows that enhanced hydrogen bonding results in a red shift. Similarly, the spectra of BPI-OH-F (N), BPI-OH-Cl (N), and BPI-OH-Br $(\mathrm{N})$ show gradually increasing red shifts from the $S_{0}$ to $S_{1}$ state, namely 335,333 , and $333 \mathrm{~cm}^{-1}$, respectively. Among the three derivatives of BPI-OH, BPI-OH-F (N) gives the highest red shift from the $\mathrm{S}_{0}$ to the $\mathrm{S}_{1}$ state. These data confirm an excited-state hydrogen-bond enhancing mechanism. The presence or absence of coordinating groups and different coordinating groups affect the hydrogen-bond strength. The presence of coordinating groups enhances hydrogen bonding, i.e., it promotes ESIPT.

Figure 3(b) shows that the $\mathrm{O}_{1}-\mathrm{H}_{2}$ vibration frequency red shifts by $120 \mathrm{~cm}^{-1}$ from $3512 \mathrm{~cm}^{-1}$ in the $S_{0}$ state to $3392 \mathrm{~cm}^{-1}$ in $S_{1}$ state. This indicates that the $\mathrm{O}_{1}-\mathrm{H}_{2} \ldots \mathrm{N}_{3}$ hydrogen bond is enhanced in the $\mathrm{S}_{1}$ state. The $\mathrm{N}_{6}-\mathrm{H}_{5}$ vibration blue shifts by $21 \mathrm{~cm}^{-1}$ from $3409 \mathrm{~cm}^{-1}$ in the $S_{0}$ state to $3430 \mathrm{~cm}^{-1}$ in the $S_{1}$ state, i.e., the $\mathrm{N}_{6}-\mathrm{H}_{5} \ldots \mathrm{O}_{4}$ hydrogen bond is stronger in the $\mathrm{S}_{0}$ state than in the $\mathrm{S}_{1}$ state. Figure $4(\mathrm{~b})$ shows red shifts of the vibration frequency of 121,122 , and $124 \mathrm{~cm}^{-1}$ in the spectra of $\mathrm{BPI}-\mathrm{OH}-\mathrm{Br}\left(\mathrm{T}_{1}\right), \mathrm{BPI}-\mathrm{OH}-\mathrm{Cl}$ $\left(T_{1}\right)$, and BPI-OH-F $\left(T_{1}\right)$, respectively. This shows that the red shift increases with increasing electron absorption intensity of the coordinating group. Figure 3(c) shows that the stretching vibration frequency of $\mathrm{N}_{3}-\mathrm{H}_{2}\left(\mathrm{~N}_{6}-\mathrm{H}_{5}\right)$ in BPI-OH $\left(\mathrm{T}_{2}\right)$ clearly blue shifts by $24 \mathrm{~cm}^{-1}$. Figure 4 (c) shows vibration frequency blue shifts of 2,6 , and $15 \mathrm{~cm}^{-1}$ for $\mathrm{BPI}-\mathrm{OH}-\mathrm{Br}\left(\mathrm{T}_{2}\right), \mathrm{BPI}-\mathrm{OH}-\mathrm{Cl}\left(\mathrm{T}_{2}\right)$, and $\mathrm{BPI}-\mathrm{OH}-\mathrm{F}\left(\mathrm{T}_{2}\right)$, respectively. This shows that the $\mathrm{N}_{3}-\mathrm{H}_{2} \ldots \mathrm{O}_{1}\left(\mathrm{~N}_{6}-\mathrm{H}_{5} \ldots \mathrm{O}_{4}\right)$ hydrogen bond is stronger in the $\mathrm{S}_{0}$ state than in the $\mathrm{S}_{1}$ state. 


\subsection{RDG analysis}

Fig. 5 shows scatter plots of RDG versus sign $\left(\lambda_{2}\right) \rho$ and the corresponding gradient isosurfaces. The RDG isosurface range is from -0.05 to 0.05 ; the hydrogen-bond isosurfaces are shown in blue. In the AIM theory, $\rho(r)$ at the critical point of a weak interaction is an important index in determining the interaction strength, and there is a positive correlation between its value and the bond strength. The larger $\rho(r)$ in the blue region is, the stronger and more attractive the weak interactions. In Fig. 5, the spikes in the small red circles correspond to attractive intramolecular hydrogen-bonding interactions. The spikes for BPI-OH-F $(\mathrm{N}), \mathrm{BPI}-\mathrm{OH}-\mathrm{Cl}(\mathrm{N})$, and $\mathrm{BPI}-\mathrm{OH}-\mathrm{Br}(\mathrm{N})$ range from -0.04 to -0.03 a.u. The spikes for $\mathrm{BPI}-\mathrm{OH}-\mathrm{F}(\mathrm{N}), \mathrm{BPI}-\mathrm{OH}-\mathrm{Cl}$ $(\mathrm{N})$ and $\mathrm{BPI}-\mathrm{OH}-\mathrm{Br}(\mathrm{N})$ are situated to the left of those for $\mathrm{BPI}-\mathrm{OH}(\mathrm{N})$. This indicates stronger intramolecular hydrogen bonds. In summary, the presence of coordinating groups strengthens hydrogen bonds, and this increases the probability of ESIPT.

\subsection{Electronic spectra, FMO analysis, and Mulliken's charge distributions}

The first excited states of BPI-OH-Br, BPI-OH-Cl and BPI-OH-F molecules were fully optimized by TDDFT/B3LYP/TZVP on the basis of their $\mathrm{S}_{0}$ state optimized structures. The absorption and emission spectra are shown in Fig. 6. The calculated absorption values for $\mathrm{BPI}-\mathrm{OH}-\mathrm{Br}(\mathrm{N}), \mathrm{BPI}-\mathrm{OH}-\mathrm{Cl}(\mathrm{N})$, and $\mathrm{BPI}-$ $\mathrm{OH}-\mathrm{F}(\mathrm{N})$ are 410, 426, and $431 \mathrm{~nm}$, respectively. The theoretical fluorescence values are 485, 505, and $512 \mathrm{~nm}$ for $\mathrm{BPI}-\mathrm{OH}-\mathrm{Br}(\mathrm{N}), \mathrm{BPI}-\mathrm{OH}-\mathrm{Cl}(\mathrm{N})$, and $\mathrm{BPI}-\mathrm{OH}-\mathrm{F}(\mathrm{N})$, respectively. These values are close to the experimental emission wavelengths. Figure 6 also shows the fluorescence spectra of BPI-OH-F $\left(T_{1}, T_{2}\right)$, BPI-OH-Cl $\left(\mathrm{T}_{1}, \mathrm{~T}_{2}\right)$, and BPI-OH-Br $\left(\mathrm{T}_{1}, \mathrm{~T}_{2}\right)$ in DCM. During ESIPT, double fluorescence emissions are observed, and large Stokes shifts are observed for $\mathrm{BPI}-\mathrm{OH}-\mathrm{Br}(\mathrm{N})(122 \mathrm{~nm}), \mathrm{BPI}-\mathrm{OH}-\mathrm{Cl}(\mathrm{N})(133 \mathrm{~nm})$ and $\mathrm{BPI}-\mathrm{OH}-\mathrm{F}(\mathrm{N})(136 \mathrm{~nm})$. The red shifts of the emission wavelengths and large Stokes shifts favor ESIPT. The addition of an $\mathrm{F}$ functional group is therefore most effective in enabling use of $\mathrm{BPI}-\mathrm{OH}$ as a probe.

Redistribution of the electron densities of proton donors and proton acceptors provide the driving force for electron-spin transfer after photoexcitation. The FMOs of $\mathrm{BPI}-\mathrm{OH}-\mathrm{Br}(\mathrm{N}), \mathrm{BPI}-\mathrm{OH}-\mathrm{Cl}(\mathrm{N})$, and $\mathrm{BPI}-\mathrm{OH}-\mathrm{F}$ $(\mathrm{N})$ are shown in Fig. 7. This shows the highest occupied molecular orbital (HOMO) and the lowest unoccupied molecular orbital (LUMO); the $\mathrm{S}_{0}-\mathrm{S}_{1}$ transitions can be described as predominantly $\pi \pi^{*}$-type transitions. The data in Table 4 show that the contributions to the excited electronic states are BPI-OH-F (N), 98.7\%; $\mathrm{BPI}-\mathrm{OH}-\mathrm{Cl}(\mathrm{N}), 98.9 \%$; and $\mathrm{BPI}-\mathrm{OH}-\mathrm{Br}(\mathrm{N}), 99.0 \%$. The order of the oscillator strengths in the $\mathrm{S}_{1}$ state is $\mathrm{BPI}-\mathrm{OH}(\mathrm{N}), 0.3802 ; \mathrm{BPI}-\mathrm{OH}-\mathrm{Br}(\mathrm{N}), 0.5038 ; \mathrm{BPI}-\mathrm{OH}-\mathrm{Cl}(\mathrm{N}), 0.4659$; and $\mathrm{BPI}-\mathrm{OH}-\mathrm{F}(\mathrm{N}), 0.3832$. The molecular optical polarizability and biological activity can be determined from the electron transition energy. The transition energies in the $\mathrm{S}_{1}$ state for $\mathrm{BPI}-\mathrm{OH}-\mathrm{Br}(\mathrm{N}), \mathrm{BPI}-\mathrm{OH}-\mathrm{Cl}(\mathrm{N})$, and $\mathrm{BPI}-\mathrm{OH}-\mathrm{F}(\mathrm{N})$ are 2.901, 2.929, and $3.016 \mathrm{eV}$, respectively (Fig. 7). The calculations show that $\mathrm{BPI}-\mathrm{OH}-\mathrm{Br}(\mathrm{N}), \mathrm{BPI}-\mathrm{OH}-\mathrm{Cl}(\mathrm{N})$, and $\mathrm{BPI}-\mathrm{OH}-\mathrm{F}(\mathrm{N})$ all have low kinetic stability and high chemical reactivity in DCM. After light excitation, the electron density is redistributed from the proton donor oxygen $\left(\mathrm{O}_{1}\right)$ in the HOMO to the proton acceptor 
nitrogen $\left(\mathrm{N}_{3}\right)$ in the LUMO. This enhances attraction to $\mathrm{H}$ and facilitates proton transfer from the enol structure to the keto structure in the $S_{1}$ state.

The data in Table 5 show that for BPI-OH-F $(\mathrm{N})$, the Mulliken's charge on $\mathrm{O}_{1}$ decreases from -0.275 to -0.270 and that on $\mathrm{N}_{3}$ increases from -0.226 to -0.236 . This indicates that the electronegativity of $\mathrm{N}_{3}$ increases and that of $\mathrm{O}_{1}$ decreases. The attraction between $\mathrm{N}_{3}$ and $\mathrm{H}$ is enhanced, which promotes ESIPT. Similar results were obtained for $\mathrm{BPI}-\mathrm{OH}-\mathrm{Cl}(\mathrm{N})$ and $\mathrm{BPI}-\mathrm{OH}-\mathrm{Br}(\mathrm{N})$. The above discussion shows that ESIPT is affected by a change in charge density.

Table 4

Calculated of electronic excitation energies $(\mathrm{nm})$, corresponding oscillator strengths $(f)$ of low-lying electronically excited states for BPI-

$\mathrm{OH}(\mathrm{N}), \mathrm{BPI}-\mathrm{OH}-\mathrm{F}(\mathrm{N}), \mathrm{BPI}-\mathrm{OH}-\mathrm{Cl}(\mathrm{N})$, and $\mathrm{BPI}-\mathrm{OH}-\mathrm{Br}(\mathrm{N})$, and orbital transition (OT) contributions to electronic excited states (Cl).

\begin{tabular}{|llllll|}
\hline & transition & $\lambda(\mathrm{nm} / \mathrm{eV})$ & $\mathrm{f}$ & $\mathrm{OT}$ & $\mathrm{Cl}(\%)$ \\
\hline $\mathrm{BPI}-\mathrm{OH}(\mathrm{N})$ & $\mathrm{S}_{0} \rightarrow \mathrm{S}_{1}$ & $433 / 2.86$ & 0.3802 & $\mathrm{H} \rightarrow \mathrm{L}$ & $99.2 \%$ \\
$\mathrm{BPI}-\mathrm{OH}-\mathrm{F}(\mathrm{N})$ & $\mathrm{S}_{0} \rightarrow \mathrm{S}_{1}$ & $410 / 3.02$ & 0.3832 & $\mathrm{H} \rightarrow \mathrm{L}$ & $98.7 \%$ \\
$\mathrm{BPI}-\mathrm{OH}-\mathrm{Cl}(\mathrm{N})$ & $\mathrm{S}_{0} \rightarrow \mathrm{S}_{1}$ & $426 / 2.91$ & 0.4659 & $\mathrm{H} \rightarrow \mathrm{L}$ & $98.9 \%$ \\
$\mathrm{BPI}-\mathrm{OH}-\mathrm{Br}(\mathrm{N})$ & $\mathrm{S}_{0} \rightarrow \mathrm{S}_{1}$ & $431 / 2.88$ & 0.5038 & $\mathrm{H} \rightarrow \mathrm{L}$ & $99.0 \%$ \\
\hline
\end{tabular}

Table 5

Calculated Mulliken's charge distributions for $\mathrm{BPI}-\mathrm{OH}(\mathrm{N})$ and its derivatives in $\mathrm{S}_{0}$ and $\mathrm{S}_{1}$ states.

\begin{tabular}{|c|c|c|c|c|c|c|}
\hline \multicolumn{7}{|c|}{ Mulliken's charge } \\
\hline & \multicolumn{2}{|l|}{$\mathrm{O}_{1}$} & \multicolumn{2}{|l|}{$\mathrm{H}_{2}$} & \multicolumn{2}{|l|}{$\mathrm{N}_{3}$} \\
\hline & $\mathrm{S}_{0}$ & $\mathrm{~S}_{1}$ & $\mathrm{~S}_{0}$ & $\mathrm{~S}_{1}$ & $\mathrm{~S}_{0}$ & $\mathrm{~S}_{1}$ \\
\hline $\mathrm{BPI}-\mathrm{OH}-\mathrm{F}(\mathrm{N})$ & -0.275 & -0.270 & 0.320 & 0.328 & -0.226 & -0.236 \\
\hline $\mathrm{BPI}-\mathrm{OH}-\mathrm{Cl}(\mathrm{N})$ & -0.273 & -0.268 & 0.318 & 0.325 & -0.227 & -0.236 \\
\hline $\mathrm{BPI}-\mathrm{OH}-\mathrm{Br}(\mathrm{N})$ & -0.277 & -0.272 & 0.318 & 0.325 & -0.228 & -0.236 \\
\hline
\end{tabular}

\subsection{PEC analysis}

PECs were constructed by step-by-step and point-to-point optimization to gain a deeper understanding of the effects of various ligands on ESIPT. As shown in Figs. 8 and 9, the PECs were constructed by keeping the $\mathrm{O}_{1}-\mathrm{H}_{2}$ and $\mathrm{O}_{4}-\mathrm{H}_{5}$ bond distances fixed at given values in steps of $0.05 \AA$, and optimizing the other 
atoms in the system without any constraints. As shown in Fig. 8, the reaction barriers for ESIPT are 4.03, $2.82,2.79$, and $2.68 \mathrm{kcal} / \mathrm{mol}$ for $\mathrm{BPI}-\mathrm{OH}, \mathrm{BPI}-\mathrm{OH}-\mathrm{Br}, \mathrm{BPI}-\mathrm{OH}-\mathrm{Cl}$, and $\mathrm{BPI}-\mathrm{OH}-\mathrm{F}$, respectively, in the $\mathrm{S}_{1}$ state. The electronic energies of the keto products $\left(T_{1}\right)$ are more stable than those of the enol reactants $(N)$, which indicates that the ESIPT reactions are exothermic. The reaction barriers for molecules with coordinating group, i.e., $\mathrm{BPI}-\mathrm{OH}-\mathrm{Br}, \mathrm{BPI}-\mathrm{OH}-\mathrm{Cl}$, and $\mathrm{BPI}-\mathrm{OH}-\mathrm{F}$, are much lower than that for $\mathrm{BPI}-\mathrm{OH}$, therefore their ESIPT reactions are easier. The energy barriers make proton transfer reactions of $\mathrm{BPI}-\mathrm{OH}, \mathrm{BPI}-\mathrm{OH}-\mathrm{Br}$, $\mathrm{BPI}-\mathrm{OH}-\mathrm{Cl}$, and $\mathrm{BPI}-\mathrm{OH}-\mathrm{F}$ in the $\mathrm{S}_{0}$ state are $10.89,9.22,6.20$, and $3.71 \mathrm{kcal} / \mathrm{mol}$, respectively. These high energy barriers make proton transfer reactions of $\mathrm{BPI}-\mathrm{OH}, \mathrm{BPI}-\mathrm{OH}-\mathrm{Br}$, and $\mathrm{BPI}-\mathrm{OH}-\mathrm{Cl}$ less likely in the $\mathrm{S}_{0}$ state than in the $S_{1}$ state. Single-proton transfer is exothermic in the $S_{1}$ state but endothermic in the $S_{0}$ state. The results show that proton transfer may occur in $\mathrm{S}_{1}$ state.

Previous studies have shown that two protons in the BPI-OH molecule are transferred step-by-step in the $\mathrm{S}_{0}$ and $\mathrm{S}_{1}$ states, i.e., proton transfer along the $\mathrm{O}_{1}-\mathrm{H}_{2}$ bond occurs only after completion of transfer of the first proton along the $\mathrm{O}_{4}-\mathrm{H}_{5}$ bond [47]. This represents a proton-relay process. Figure 9 shows that for $\mathrm{T}_{1} \rightarrow \mathrm{T}_{2}$, the reaction barriers for ESIPT are $7.88,6.62,6.54$, and $6.49 \mathrm{kcal} / \mathrm{mol}$ for $\mathrm{BPI}-\mathrm{OH}, \mathrm{BPI}-\mathrm{OH}-\mathrm{Br}, \mathrm{BPI}-$ $\mathrm{OH}-\mathrm{Cl}$, and $\mathrm{BPI}-\mathrm{OH}-\mathrm{F}$, respectively, in the $\mathrm{S}_{1}$ state. Compared with the energy barriers for proton transfer along the $\mathrm{O}_{1}-\mathrm{H}_{2}$ bond in the first step, the corresponding values for the $\mathrm{O}_{4}-\mathrm{H}_{5}$ bond are much higher in both the $\mathrm{S}_{0}$ and $\mathrm{S}_{1}$ states. Reaction barrier is lowest for BPI-OH-F, therefore the ESIPT reaction occurs more easily. In summary, substituent modification facilitates ESIPT, and the higher the electron absorption intensity, the lower the energy barrier for a proton-transfer reaction.

\section{Conclusions}

In summary, new insights into substituent modification and the ESIDPT mechanism for symmetric structures of BPI-OH and its derivatives were obtained by using DFT/TDDFT methods. Comparisons of the changes in the primary bond parameters confirmed that substituent modification strengthened excited-state intermolecular hydrogen bonds. Analysis of PECs in the $S_{0}$ and $S_{1}$ states showed that proton transfer involved two steps in the $S_{1}$ state, and was difficult to achieve in the $S_{0}$ state. Our results suggest that strengthening of intramolecular hydrogen bonds can effectively decrease the energy barriers and promote the proton-transfer process. Modification with electron-withdrawing groups $(\mathrm{F}, \mathrm{Cl}$, and $\mathrm{Br})$ favors proton-transfer reactions. These distinctive properties will enable control of ESIDPT processes and provide guidance for the design and synthesis of similar molecules.

\section{Declarations}

\section{Funding}

The open fund of the state key laboratory of molecular reaction dynamics in DICP, CAS is provided by Yi Wang. 


\section{Conflicts of interest}

There are no conflicts of interest.

Availability of data and material Not applicableCode availability Not applicableAuthors' contributions

Xiumin Liu: Investigation,Writing - original draft

Wenzhi Li: Investigation

Yuxi Wang:Data curation

Yaping Tao:Data curation

Yi Wang:Writing - review \& editing, Funding acquisition

Yingmin Hou:Conceptualization, Writing - review\& editing

\section{Acknowledgements}

This work was supported by the Open Project of SKLMRD ( the open fund of the state key laboratory of molecular reaction dynamics in DICP, CAS).

\section{References}

1. Meyer TJ, Huynh MHV, Thorp, HH (2007) The Possible Role of Proton-Coupled Electron Transfer (PCET) in Water Oxidation by Photosystem II. Angew Chem Int Ed 46:5284-5304

2. Tseng HW, Shen JY, Kuo TY, Tu TS, Chen YA, Demchenko AP, Chou PT (2016) Excited-state intramolecular proton-transfer reaction demonstrating anti-kasha behavior. Chem Sci 7:655-665

3. Goodman J, Brus LE (1979) Proton transfer and tautomerism in an excited state of methyl salicylate. J Am Chem Soc 10:7472-7474

4. Sytnik A, Kasha M (1994) Excited-state intramolecular proton transfer as a fluorescence probe for protein binding-site static polarity. Proc Natl Acad Sci U S A 91:8627-8630

5. Kukura P, McCamant DW, Mathies RA (2007) Femtosecond Stimulated Raman Spectroscopy. Rev Phys Chem 58:461-488

6. Meech SR (2009) Excited State Reactions in Fluorescent Proteins. Chem Soc Rev 38:2922-2934

7. Martinez TJ (2006) Insights for Light-Drive. Acc Chem Res 39:119-126

8. Zhao J, Ji S, Chen Y, Guo H, Yang P (2012) Excited state intramolecular proton transfer (ESIPT): from principal photophysics to the development of new chromophores and applications in fluorescent molecular probes and luminescent materials. Phys Chem Chem Phys 14:8803-8817

9. Ma DG, Liang FS, Wang LX, Lee ST, Hung LS (2002) Blue organic light-emitting devices with an oxadiazole-containing emitting layer exhibiting excited state intramolecular proton transfer. Chem 
Phys Lett 358:24-28

10. Chou PT, Studer SL, Martinez ML (1991) Practical and Convenient 355-nm and 337-nm Sharp-Cut Filters for Multichannel Raman Spectroscopy. Appl Spectrosc 45:513-515

11. Liu B, Wang H, Wang T, Bao Y, Du F, Tian J, Li Q, Bai R (2012) A new ratiometric ESIPT sensor for detection of palladium species in aqueous solution. Chem Commun 48:2867-2869

12. Lou ZR, Li P, Han KL (2015) Redox-Responsive Fluorescent Probes with Different Design Strategies. Acc Chem Res 48:1358-1368

13. Zhu Q, Wen K, Feng S, Wu W, An B, Yuan H, Guo X, Zhang J (2017) Theoretical insights into the excited-state intramolecular proton transfer (ESIPT) mechanism in a series of amino-type hydrogenbonding dye molecules bearing the 10-aminobenzo [h]quinoline chromophore. Dyes Pigments 141:195-201

14. Lim SJ, Seo J, Park SY (2006) Photochromic Switching of Excited-State Intramolecular ProtonTransfer (ESIPT) Fluorescence: A Unique Route to High-Contrast Memory Switching and Nondestructive Readout. J Am Chem Soc 128:14542-14547

15. Tang KC, Chang MJ, Lin TY, Pan HA, Fang TC, Chen KY, Hung WY, Hsu YH, Chou PT (2011) Fine Tuning the Energetics of Excited-State Intramolecular Proton Transfer (ESIPT): White Light Generation in A Single ESIPT System. J Am Chem Soc 133:17738-17745

16. Liu YH, Lan SC, Zhu CY, Lin SH (2015) Intersystem Crossing Pathway in Quinoline Cpyrazole Isomerism: A Timedependent Density Functional Theory Study on Excited-state Intramolecular Proton Transfer. J Phys Chem A 119:6269-6274

17. Yu FB, Li P, Wang BS, Han KL (2013) Reversible Near-Infrared Fluorescent Probe Introducing Tellurium to Mimetic Glutathione Peroxidase for Monitoring the Redox Cycles between Peroxynitrite and Glutathione in Vivo. J Am Chem Soc 135:7674-7680

18. Lan RF, Yang YF, Yan ZM, Li YQ (2017) The theoretical study of excited-state intramolecular proton transfer of 2,5-bis(benzoxazol-2-yl)thiophene-3,4-diol. Spectrochimica Acta Part A: Molecular and Biomolecular Spectroscopy 183:37-44

19. Randino C, Ziółek M, Gelabert R, Organero JA, Gil M, Moreno M, Lluch JM, Douhal A (2011) Photodeactivation pathways of a double $\mathrm{H}$-bonded photochromic Schiff base investigated by combined theoretical calculations and experimental time-resolved studies. Phys Chem Chem Phys 13:14960-14972

20. Falkovskaia E, Pivovarenko VG, Valle JC (2003) Interplay between Intra- and Intermolecular ExcitedState Single- and Double-Proton-Transfer Processes in the Biaxially Symmetric Molecule 3,7Dihydroxy-4H,6H-pyrano[3,2-g]-chromene-4,6-dione. J Phys Chem A 107:3316-3325

21. Roshal AD, Moroz VI, Pivovarenko VG, Wróblewska A, Błażejowski J (2003) Spectral and Acid-Base Features of 3,7-Dihydroxy-2,8-diphenyl-4H,6H-pyrano[3,2-g]chromene-4,6-dione (Diflavonol)A Potential Probe for Monitoring the Properties of Liquid Phases. J Org Chem 68:5860-5869

22. Raymo FM, Bartberger MD, Houk KN, Stoddart JF (2001) The magnitude of [C-H...O] hydrogen bonding in molecular and supramolecular assemblies. J Am Chem Soc 123:9264-9267 
23. Mohamed A, Fahim AM, Ibrahim SAE (2021) Studies on hydrogen bonding of adrenaline/acetone and adrenaline/methanol complexes: computational and experimental approach. Struct Chem https://doi.org/10.1007/s11224-021-01773-3

24. Nowroozi A, Housaindokht MR, Nakhaei E (2021) A detail investigation of synergistic effects between the intramolecular hydrogen bond and $\pi$-electron delocalization in 3-hydroxy prop-2-en thial and its derivatives. Struct Chem 32:709-718

25. Zhao GJ, Han KL (2008) Time-dependent density functional theory study on hydrogen-bonded intramolecular charge-transfer excited state of 4-dimethylamino-benzonitrile in methanol. J Comput Chem 29:2010-2017

26. Zhao GJ, Han KL (2012) Hydrogen Bonding in the Electronic Excited State. Acc Chem Res 45:404-413

27. Qi YT, Tang Z, Zhan HB, Wang Y, Zhao Y, Xu F, Jing TN, Ling YD, Liu JY (2020) A new interpretation of the ESIPT mechanism of 2-(benzimidazol-2-yl)-3-hydroxychromone derivatives. Spectrochim Acta A Mol Biomol Spectrosc 117359

28. Zhao GJ, Han KL (2010) PH-controlled twisted intramolecular charge transfer (TICT) excited state via changing the charge transfer direction, Phys Chem Chem Phys 12:8914-8918

29. Yang G, Chen KF, Wang G, Yang DP (2020) TDDFT investigation on electronically excited-state hydrogen-bonding properties and ESIPT mechanism for the 2-(1H-imidazol-2-yl)-phenol compound. Struct Chem 32:997-1003

30. Ji EK, Park SY (2011) Advanced organic optoelectronic materials: harnessing excited-state intramolecular proton transfer (ESIPT) process. Adv Mater 23:3615-3642

31. Hsieh CC, Jiang CM, Chou PT (2010) Recent experimental advances on excited-state intramolecular proton coupled electron transfer reaction. Acc Chem Res 43:1364-1374

32. Zhao J, Ji S, Chen Y, Guo H, Yang P (2012) Excited state intramolecular proton transfer (ESIPT): from principal photophysics to the development of new chromophores and applications in fluorescent molecular probes and luminescent materials. Phys Chem Chem Phys 14:8803-8817

33. Adebayo AA, Jeanet C (2021) Exploring substituents and solvent effects on the reduction potential and molecular properties of five derivatives of hydroxybenzophenone (HBP) with their possible conformations and isomers. Struct Chem 32:1299-1310

34. Piechowska J, Angulo G (2019) Frustrated excited state intramolecular proton transfer (ESIPT) in 10hydroxy-11H-benzo[b]fluoren-11-one: Synthesis and photophysics. Dyes and Pigments 165:346-353

35. Yu XF, Sun XY, Xiao B, Liu ZB, Cheng JB, Yang X, Li WZ, Li QZ (2019) Screening NIR fluorescent sensor based on HBQ derivatives: A theoretical study. Journal of Photochemistry \& Photobiology A: Chemistry 383:111989

36. Kataria S, Rhyman L, Ramasami P, Sekar N (2016) Comprehensive DFT and TD-DFT Studies on the Photophysical Properties of 5,6-Dichloro-1,3-Bis(2-Pyridylimino)-4,7-Dihydroxyisoindole: A New Class of ESIPT Fluorophore. J Fluoresc 26:1805-1812 
37. Tao YP, Han LG, Han YX, Liu ZJ (2015) Apoptosis of acute myeloid leukemia HL-60 cells induced by CDK inhibitor SNS-032 and its molecular mechanisms. Spectrochim Acta Part A 137:892-898

38. Frisch MJ, Trucks GW, Schlegel HB, Scuseria GE, Robb MA, Cheeseman JR, Scalmani G, Barone V, Petersson GA, Nakatsuji H, Li X, Caricato M, Marenich AV, Bloino J, Janesko BG, Gomperts R, Mennucci B, Hratchian HP, Ortiz JV, Izmaylov AF, Sonnenberg JL, Williams-Young D, Ding F, Lipparini F, Egidi F, Goings J, Peng B, Petrone A, Henderson T, Ranasinghe D, Zakrzewski VG, Gao J, Rega N, Zheng G, Liang W, Hada M, Ehara M, Toyota K, Fukuda R, Hasegawa J, Ishida M, Nakajima T, Honda Y, Kitao O, Nakai H, Vreven T, Throssell K, Montgomery Jr JA, Peralta JE, Ogliaro F, Bearpark MJ, Heyd JJ, Brothers EN, Kudin KN, Staroverov VN, Keith TA, Kobayashi R, Normand J, Raghavachari K, Rendell AP, Burant JC, lyengar SS, Tomasi J, Cossi M, Millam JM, Klene M, Adamo C, Cammi R, Ochterski JW, Martin RL, Morokuma K, Farkas O, Foresman JB, Fox DJ (2016) M. A. Gaussian 16, Revision C. 01, Gaussian, Inc., Wallingford, CT

39. Schafer A, Horn H, Ahlrichs R (1992) Fully optimized contracted Gaussian basis sets for atoms Li to Kr. J Chem Phys 97:2571-2577

40. Schafer A, Huber C, Ahlrichs R (1994) Fully optimized contracted Gaussian basis sets of triple zeta valence quality for atoms $\mathrm{Li}$ to $\mathrm{Kr}$, J Chem Phys 100:5829-5835

41. Cammi R, Tomasi J (1995) Remarks on the use of the apparent surface charges (ASC) methods in solvation problems: iterative versus matrix-inversion procedures and the renormalization of the apparent charges. J Comput Chem 16:1449-1458

42. Cances E, Mennucci B, Tomasi J (1997) A new integral equation formalism for the po-larizable continuum model: theoretical background and applications to isotropic and anisotropic dielectrics. $J$ Chem Phys 107:3032-3041

43. Mennucci B, Cances E, Tomasi J (1997) Evaluation of solvent effects in isotropic and anisotropic dielectrics and in ionic solutions with a unified integral equation method: theoretical bases, computational implementation, and numerical applications. J Phys Chem B 101:10506-10517

44. Lu T, Chen FW (2012) Multiwfn: a multifunctional wavefunction analyzer. J Comput Chem 33:580592

45. Garcia JC, Johnson ER, Keinan S, Chaudret R, Piquemal JP, Beratan DN, Yang WT (2011) NCIPLOT: a program for plotting non-covalent interaction regions. J Chem Theory Comput 7:625-632

46. Johnson ER, Keinan S, Mori-Sanchez P, Contreras-Carcia J, Cohen AJ, Yang WT (2010) J Am Chem Soc 132:6498-6506

47. Driscoll E, Sorenson S, Dawlaty JM (2015) Ultrafast Intramolecular Electron and Proton Transfer in Bis(imino)isoindole Derivatives. J Phys Chem A 119:5618-25

\section{Figures}




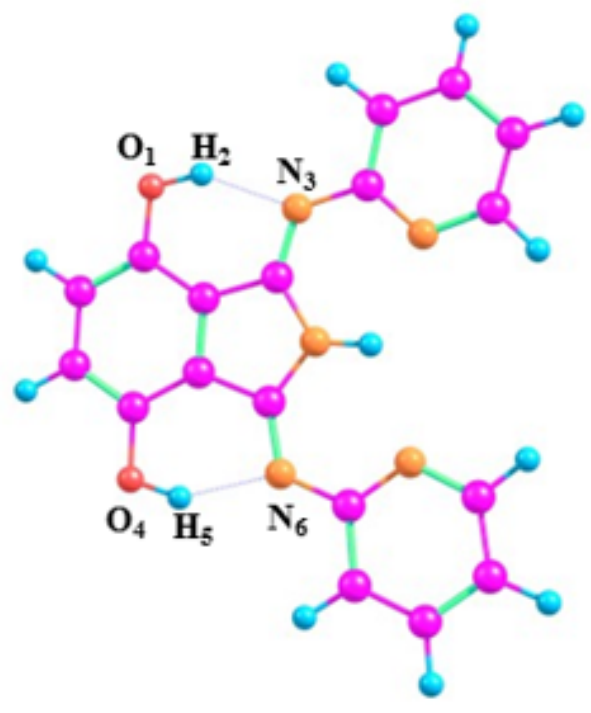

BPI-OH (N)

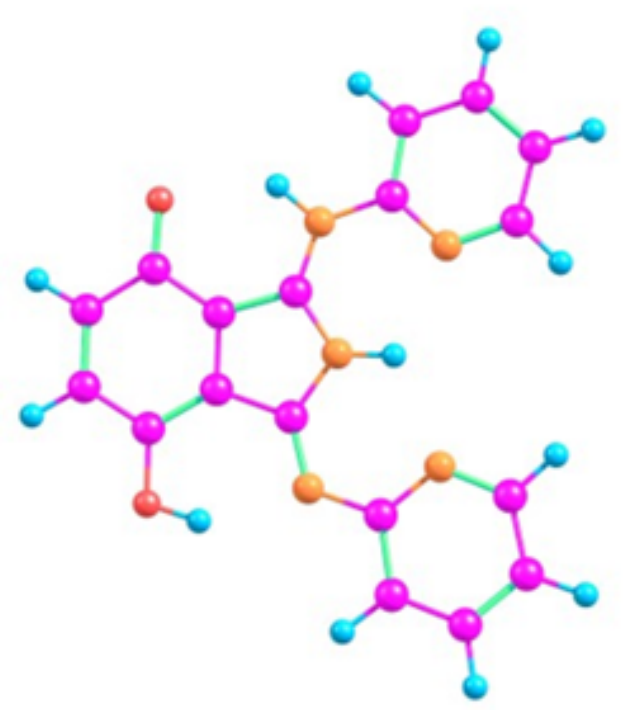

BPI-OH $\left(\mathrm{T}_{1}\right)$

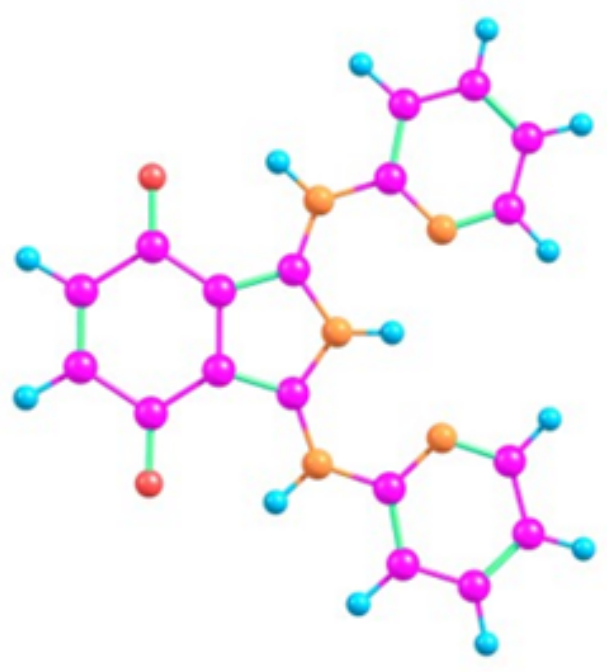

BPI-OH $\left(\mathrm{T}_{2}\right)$

\section{Figure 1}

Structures of BPI-OH (N), BPI-OH (T1) (single-proton transfer of BPI-OH), and BPI-OH (T2) (double-proton transfer of $\mathrm{BPI}-\mathrm{OH})$. Atoms involved in two intramolecular hydrogen bonds are indicated in the BPI-OH structure.

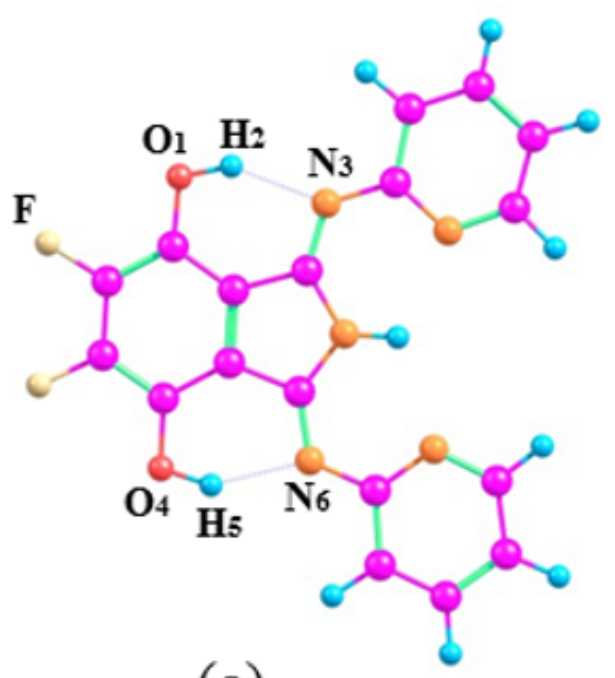

(a)

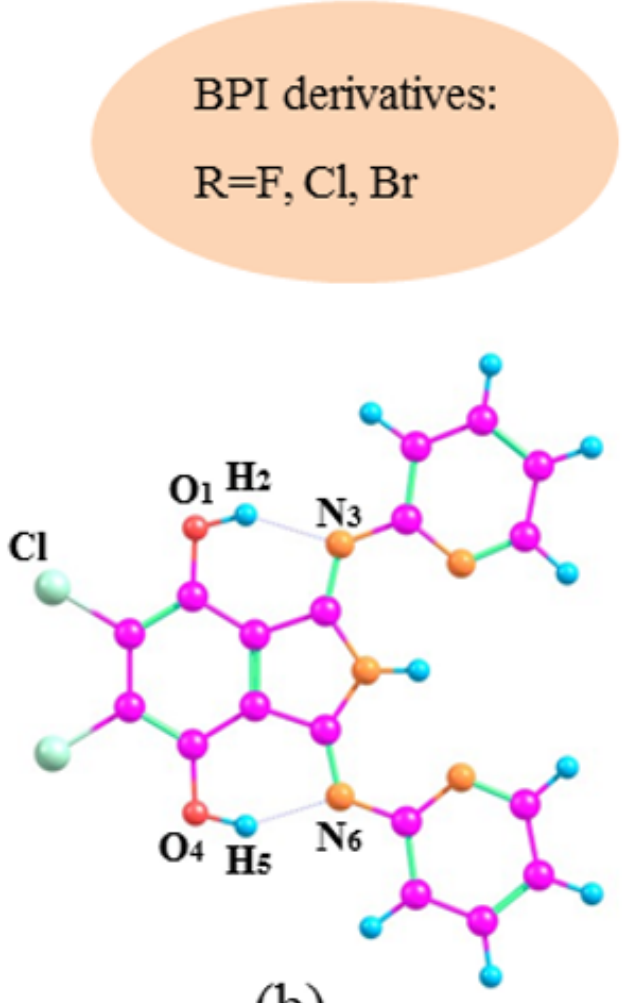

(b)

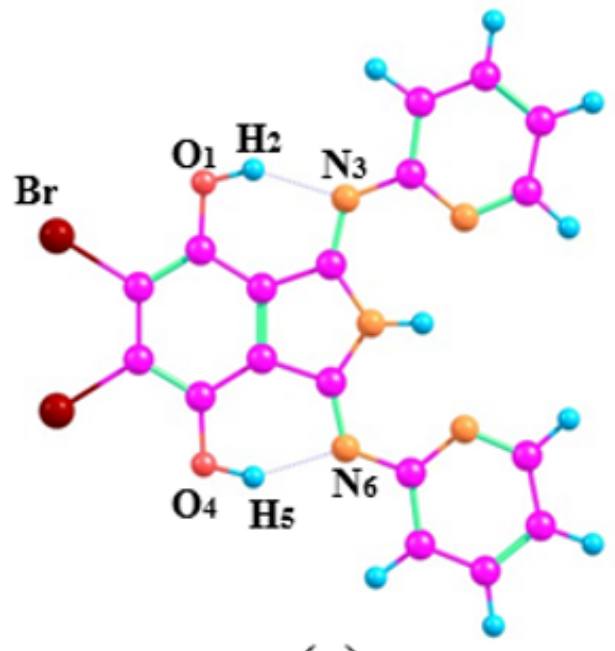

(c)

Figure 2

Optimized structures of BPI-OH derivatives: (a) BPI-OH-F, (b) BPI-OH-Cl, and (c) BPI-OH-Br. 


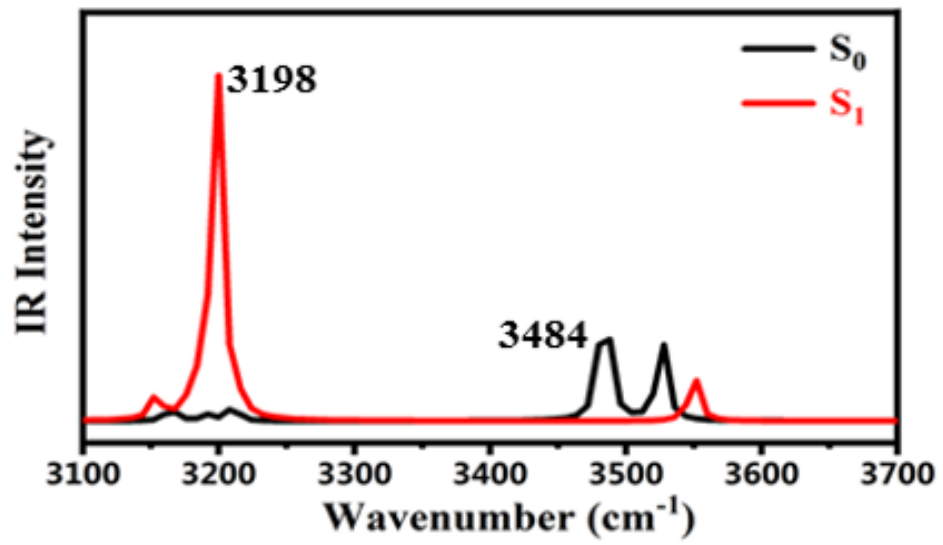

(a)

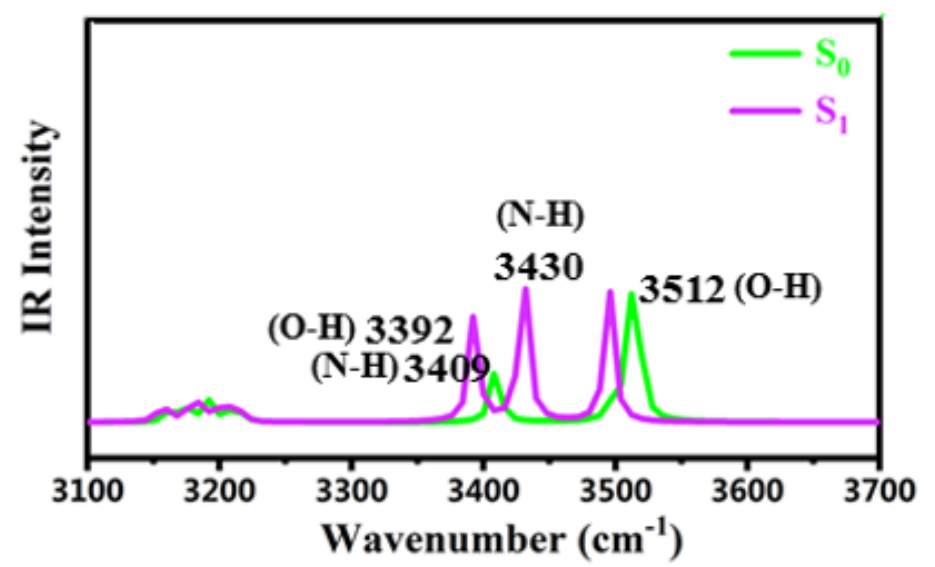

(b)

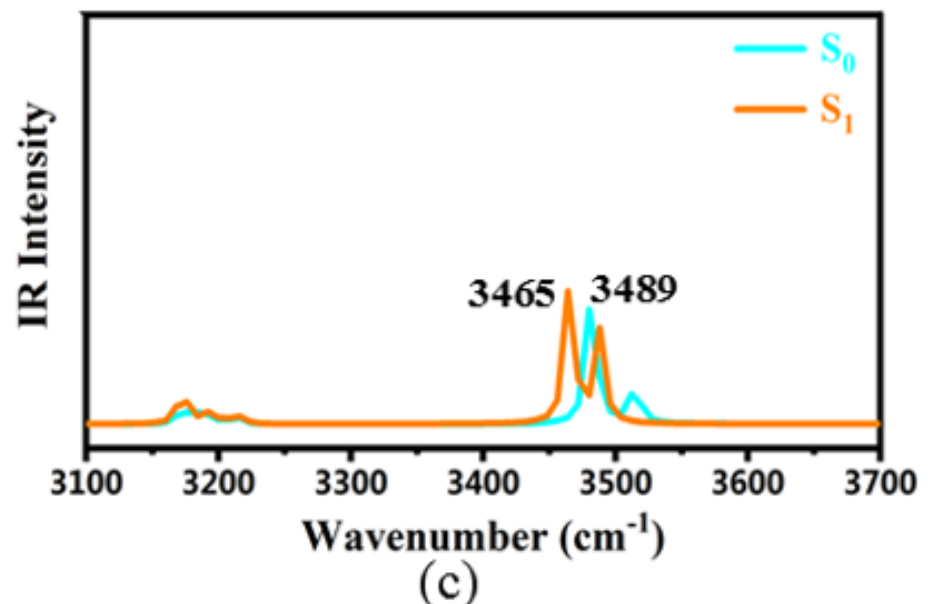

(c)

Figure 3

IR spectra (B3LYP/TZVP): (a) 01-H2 (O4-H5) in BPI-OH (N); (b) 01-H2 and N6-H5 in BPI-OH (T1); and (c) $\mathrm{N} 3-\mathrm{H} 2$ (N6-H5) in BPI-OH (T2). 


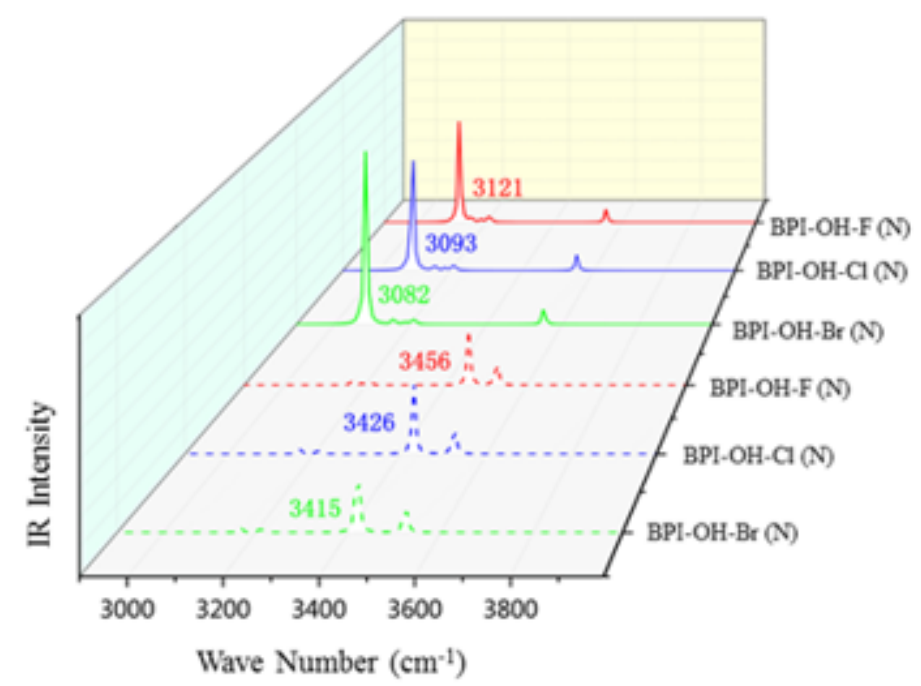

(a)

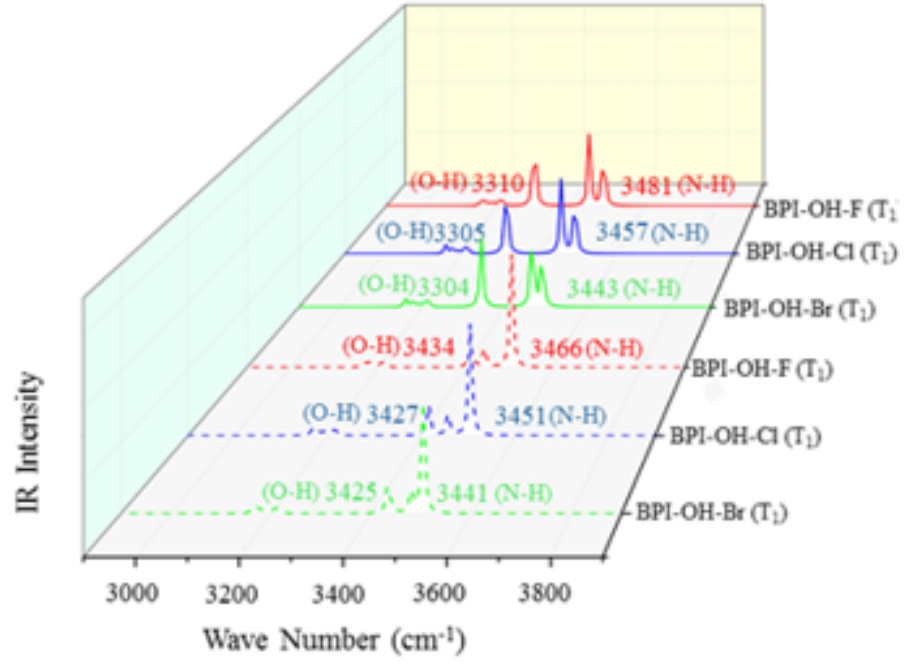

(b)

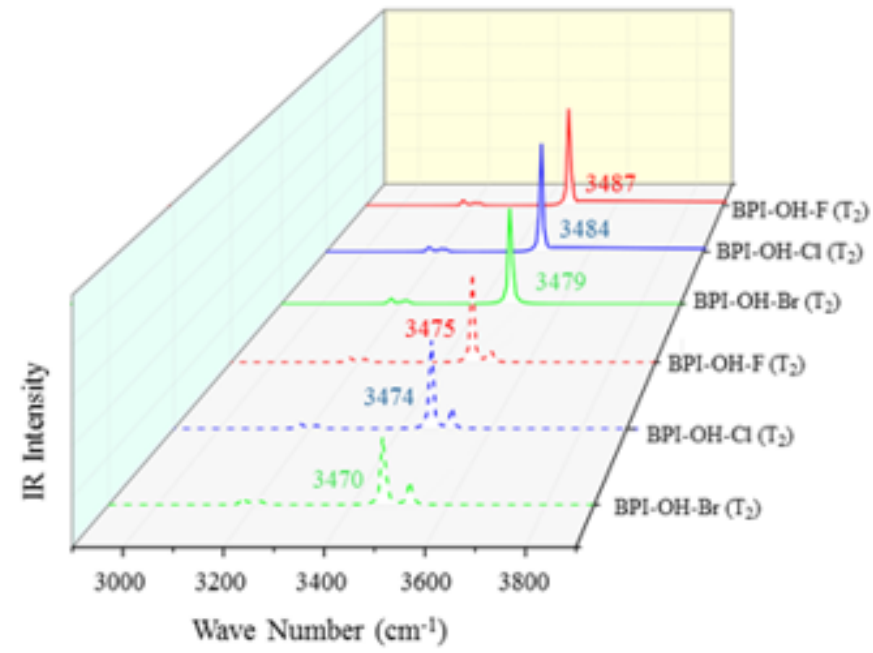

(c)

\section{Figure 4}

IR spectra (B3LYP/TZVP): (a) 01-H2 (O4-H5) in BPI-OH-F (N), BPI-OH-Cl (N), and BPI-OH-Br (N); (b) 01-H2 and $\mathrm{N} 6-\mathrm{H} 5$ in BPI-OH-F (T1), BPI-OH-Cl (T1), and BPI-OH-Br (T1); and (c) N3-H2 (N6-H5) in BPI-OH-F (T2), $\mathrm{BPI}-\mathrm{OH}-\mathrm{Cl}$ (T2), and BPI-OH-Br (T2). (dotted lines: S0; solid lines:S1) 


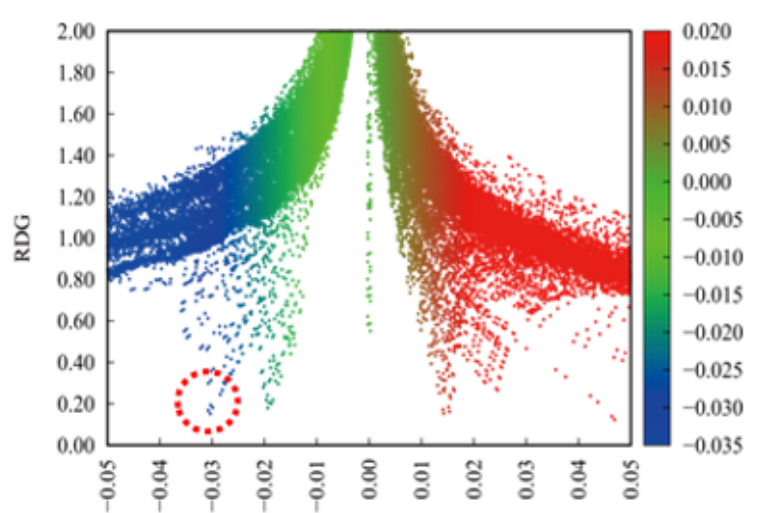

$\operatorname{sign}\left(\mathrm{l}_{2}\right) \mathrm{r}(\mathrm{a.u}$.

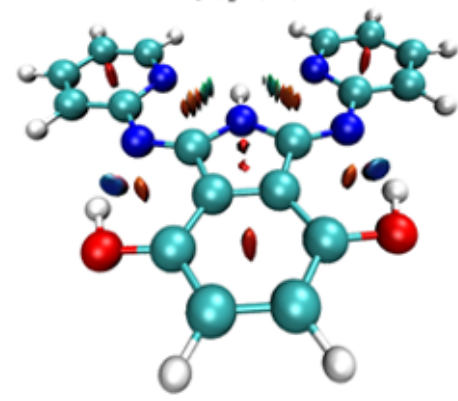

BPI-OH (N)

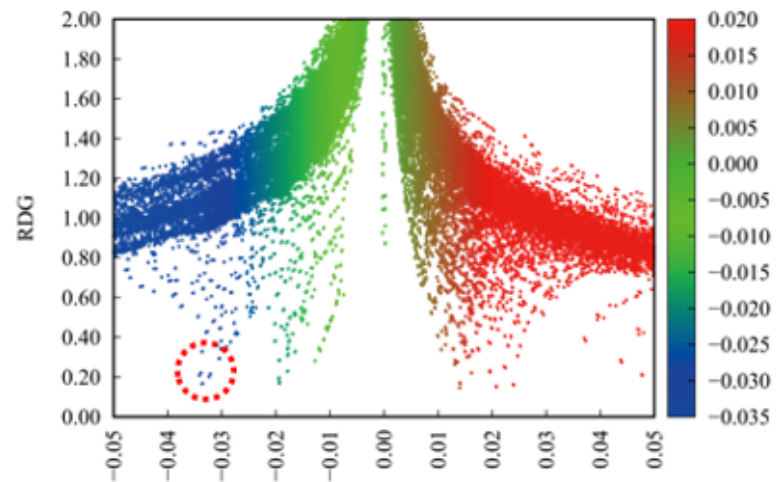

$\operatorname{sign}\left(1_{2}\right) r($ a.u. $)$

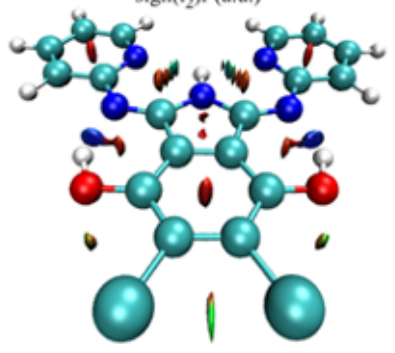

BPI-OH-Cl (N)

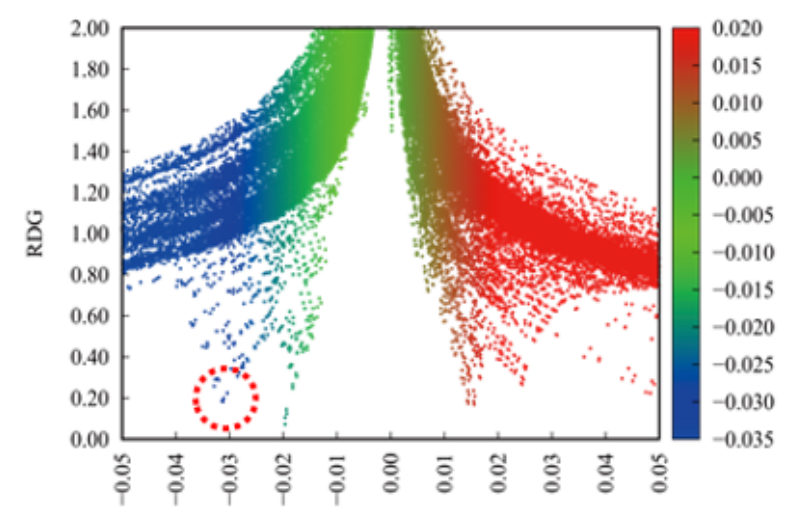

$\operatorname{sign}\left(I_{2}\right) r$ (a.u.)

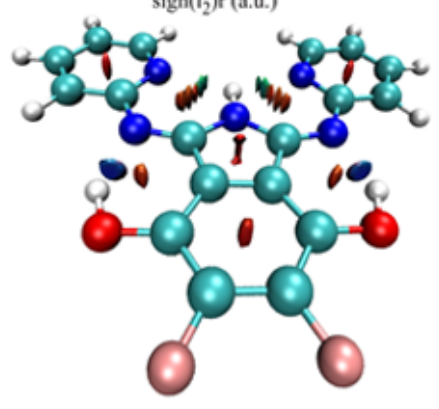

BPI-OH-F (N)

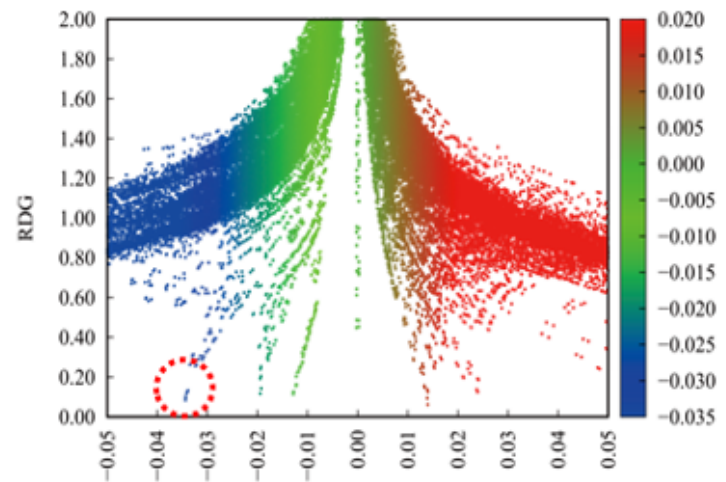

$\operatorname{sign}\left(1_{2}\right) r(a . u$. $)$

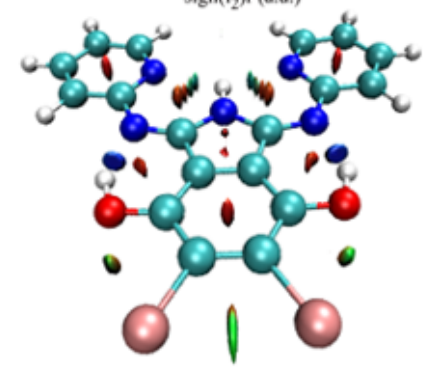

BPI-OH-Br (N)

Figure 5

Plots of RDG versus electron density multiplied by sign of second Hessian eigenvalue and color-mapped RDG isosurfaces for BPI-OH (N) and its derivatives in $\mathrm{S} 1$ state. 


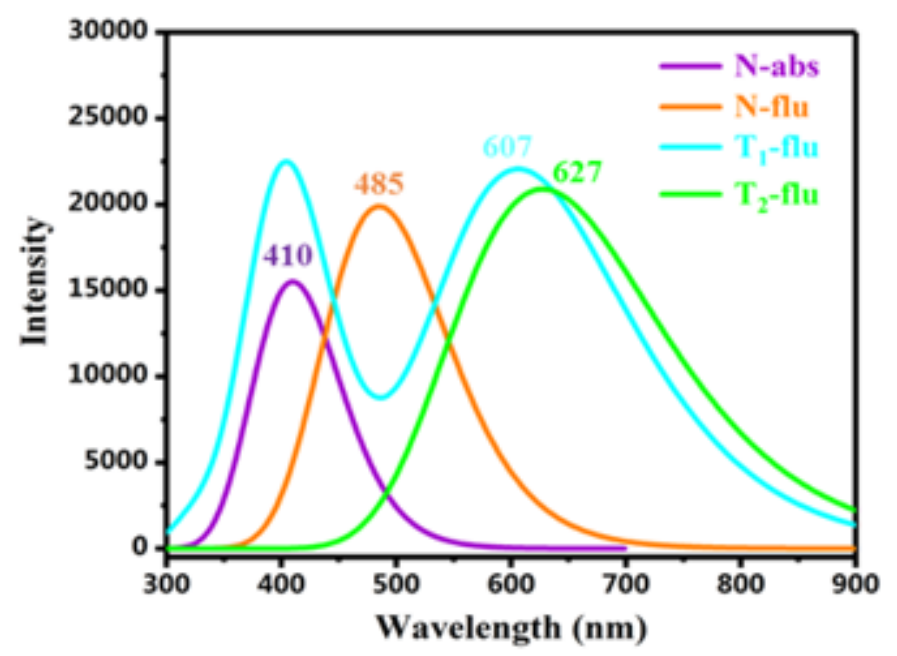

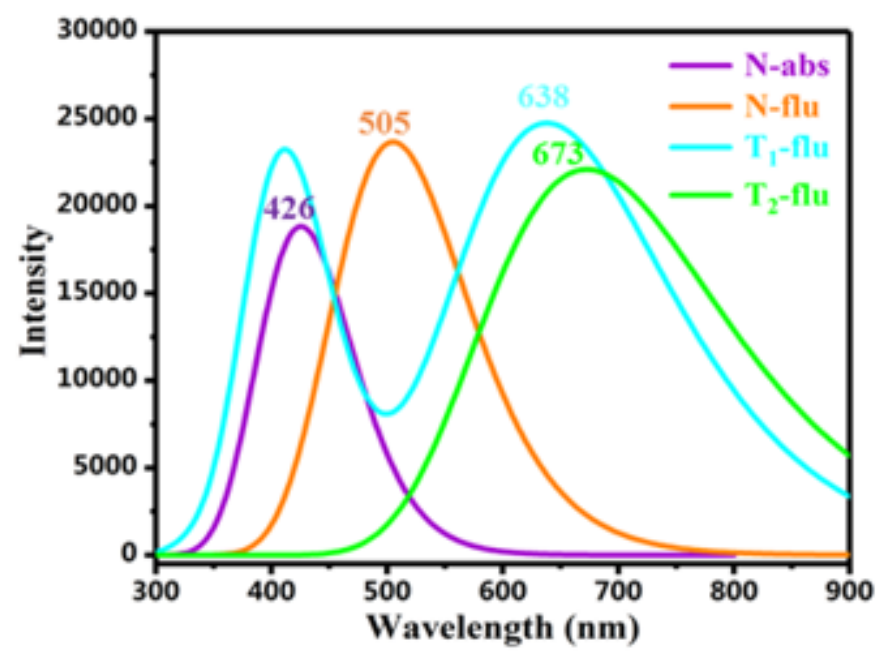

(b) (a)

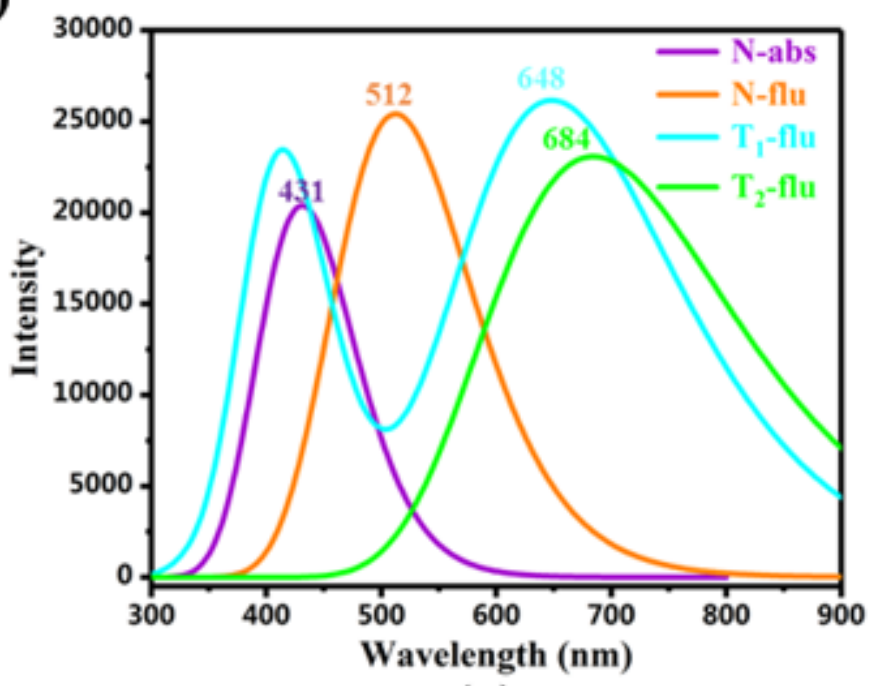

(c)

Figure 6

Calculated absorption (abs) and fluorescence (flu) wavelengths for (a) BPI-OH-Br, (b) BPI-OH-Cl, and (c) BPI-OH-F; N: normal form; T1 and T2: tautomeric forms. 


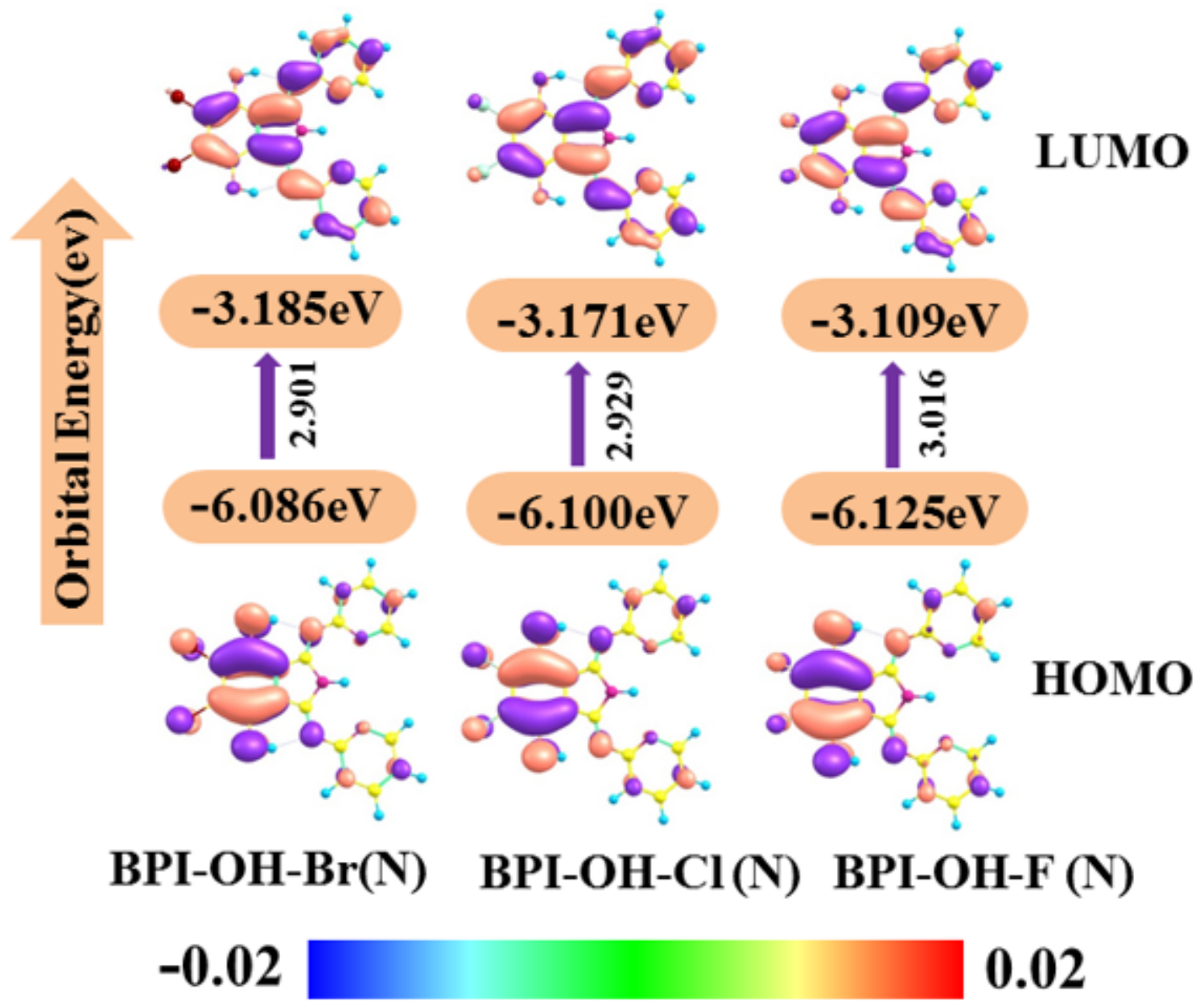

Figure 7

Calculated FMOs (HOMOs and LUMOs) for BPI-OH (N), BPI-OH-Br (N), BPI-OH-Cl (N), and BPI-OH-F (N) in S1 state and their transition energies. 


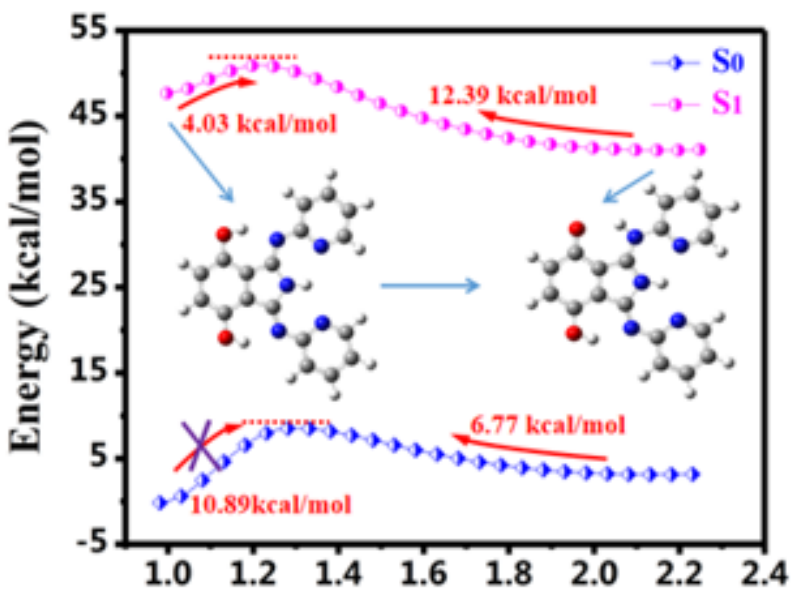

Distance of O-H ( $(\AA)$

(a)

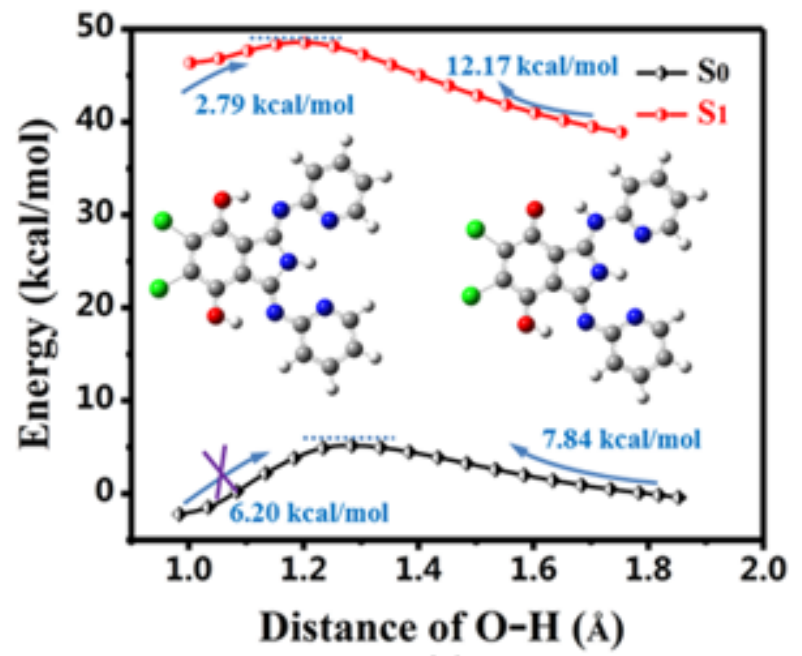

(c)

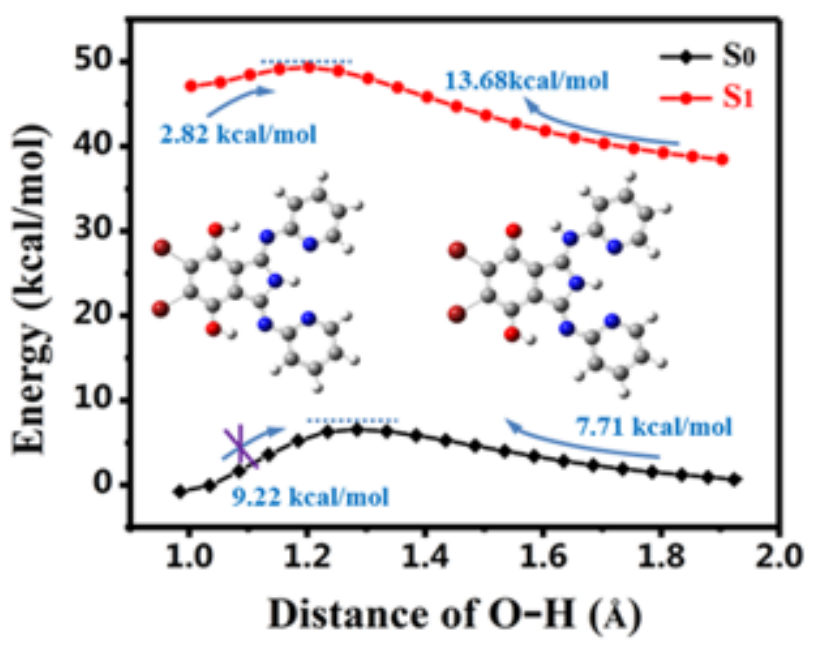

(b)

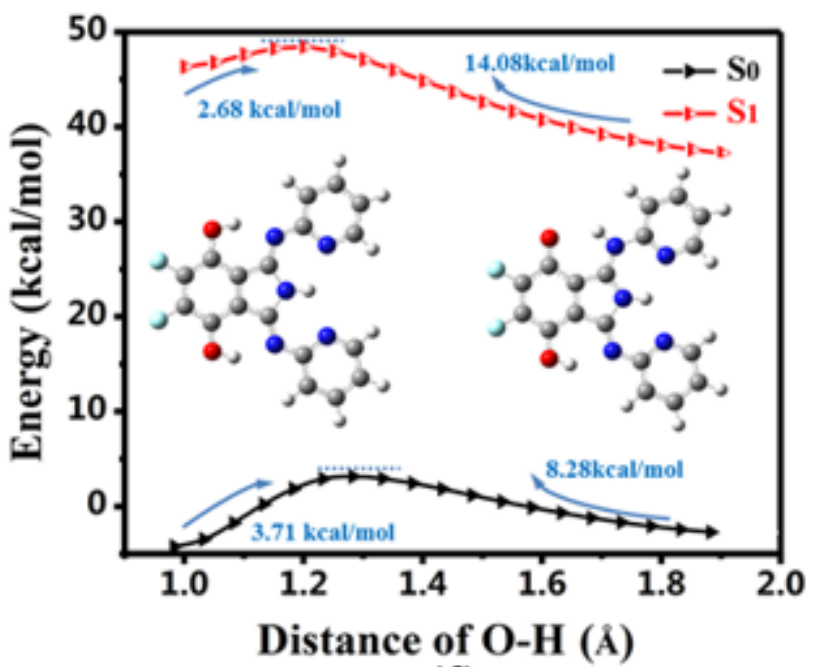

(d)

Figure 8

PECs for S0 and S1 states of BPI-OH (N), BPI-OH-Br $(\mathrm{N}), \mathrm{BPI}-\mathrm{OH}-\mathrm{Cl}(\mathrm{N})$, and BPI-OH-F $(\mathrm{N})$, and $01-\mathrm{H} 2$ bond lengths. The insets show corresponding optimized configurations $(\mathrm{N} \rightarrow \mathrm{T} 1)$ : (a) $\mathrm{BPI}-\mathrm{OH},(\mathrm{b}) \mathrm{BPI}-\mathrm{OH}-\mathrm{Br},(\mathrm{c})$ $\mathrm{BPI}-\mathrm{OH}-\mathrm{Cl}$, (d) BPI-OH-F. 


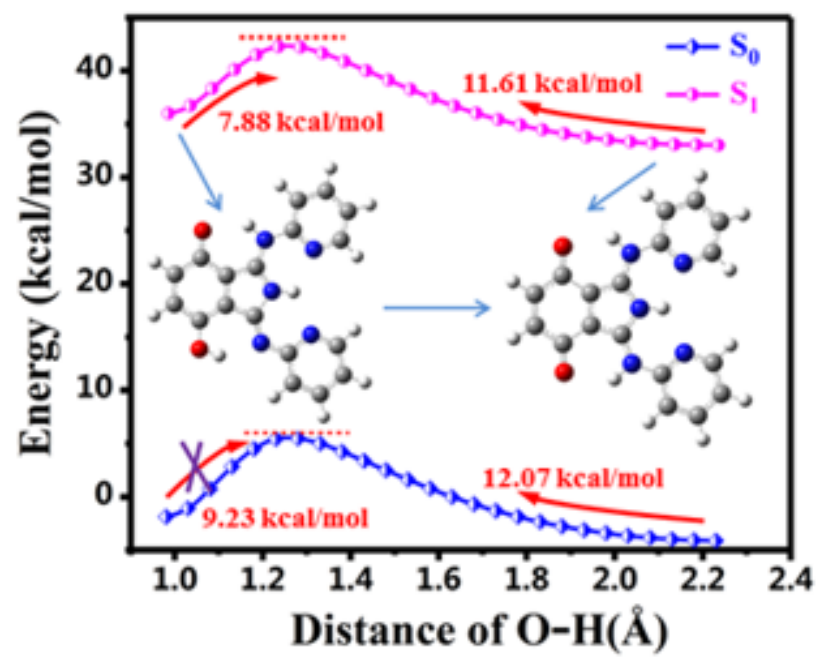

(A)

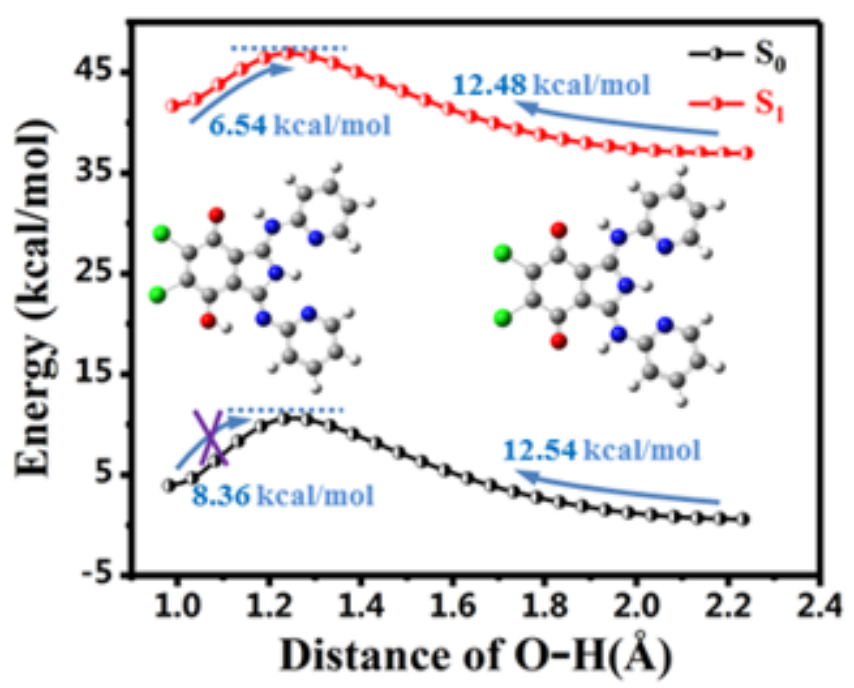

(C)

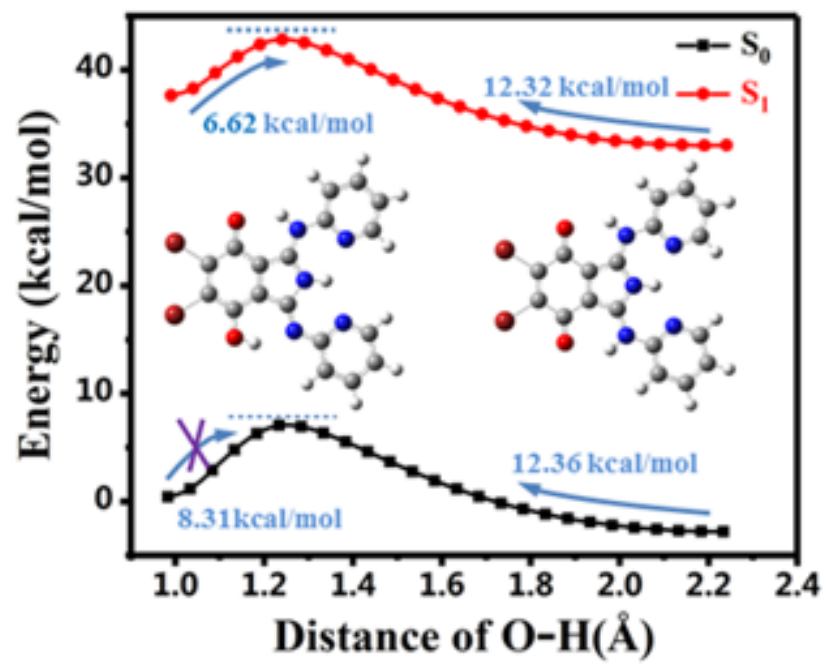

(B)

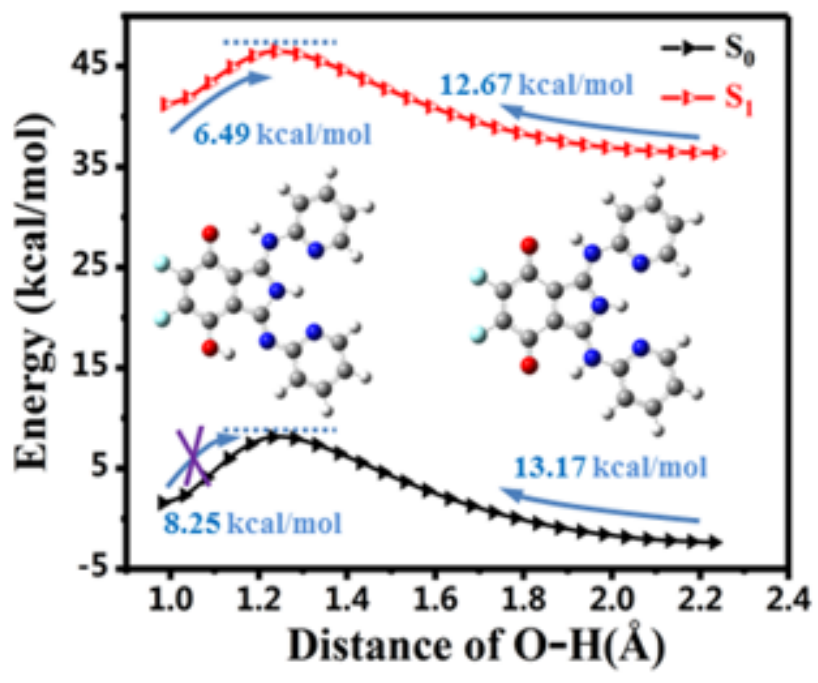

(D)

Figure 9

PECs for S0 and S1 states of BPI-OH (T1), BPI-OH-Br (T1), BPI-OH-Cl (T1), and BPI-OH-F (T1), and O4-H5 bond lengths. The insets show the corresponding optimized configurations (T1 $\rightarrow$ T2): (a) BPI-OH, (b) BPI$\mathrm{OH}-\mathrm{Br}$, (c) BPI-OH-Cl, (d) BPI-OH-F. 